\title{
SENDENG-BARAT DALAM SASTERA MELAYU MODEN: \\ CABARAN SEBUAH CENGKAMAN ${ }^{1}$ \\ Western-bias in Modern Malay Literature: \\ The Challenge of a Stranglehold
}

\author{
UNGKU MAIMUNAH MOHD. TAHIR \\ Institut Alam dan Tamadun Melayu (ATMA) \\ Universiti Kebangsaan Malaysia \\ 43600 Bangi \\ ungkumaimunah@yahoo.com \\ Dihantar: 8 Julai 2019 / Diterima: 18 Oktober 2019
}

\begin{abstract}
Abstrak Walaupun begitu kerap dilaungkan peri pentingnya kita mengguna kerangka dan teori tempatan untuk menangani sastera tanah air, hakikatnya sastera Melayu begitu bergantung kepada Barat untuk segala urusan berkaitan sastera termasuklah penghasilan, penilaian dan pengiktirafan sastera. Bagaimanakah teori dan kerangka Barat dapat mendominasi kegiatan sastera Melayu, mengekalkan kerelevanannya dan dipertahankan kegunaannya oleh penulis dan pengkritik Melayu sendiri sehingga kegiatan sastera Melayu memperlihatkan kesendengan Barat yang nyata? Kajian ini mengutarakan empat faktor yang menyebabkan perkara ini berlaku iaitu pertama, faktor sejarah sastera itu sendiri yang dibikin oleh sarjana dan pentadbir Barat menurut acuannya dan seterusnya diterima oleh sarjana tempatan dan diperpanjangkan oleh mereka; kedua, faktor sikap yang dilentur untuk melihat dan menerima Barat serta tradisi sasteranya sebagai moden dan unggul, sementara tradisi sendiri khususnya yang berteraskan Islam dilihat sebagai kolot dan ketinggalan zaman; ketiga, faktor peranan institusi penting seperti Dewan Bahasa dan Pustaka (DBP) yang melalui autoriti dan kuasa yang dibekalkan kepadanya, memastikan kebergantungan kepada Barat dipraktikkan secara konsisten tanpa banyak pertikaian; dan keempat, faktor memantapkan tatacara sastera Barat sebagai praktik yang sesuai dan relevan bagi kegiatan sastera, dengan itu menjadikan tatacara tersebut sebagai konvensi sastera yang sah dan boleh digunakan dengan selesa tanpa bimbang akan dipertikaikan atau disanggah. Dengan beroperasinya empat faktor tersebut secara berterusan dan konsisten, kesendengan Barat dalam sastera Melayu menjadi satu kenyataan yang tidak dapat dinafikan, sekali gus menjadi satu cengkaman yang cukup mencabar.
\end{abstract}


Kata kunci: Kesendengan Barat, bikinan sejarah, konvensi sastera, autoriti institusi, lenturan sikap, cengkaman.

Abstract Despite repeated and sustained claims to the contrary, modern Malay literature unabashedly demonstrates a penchant for and continued use of Western literary theories and paradigms for both its creative and critical works. What makes it possible for Western paradigms to dominate Malay literary activities, continue to sustain their relevance, and elicit support for their continued use from Malay writers and critics? This article examines four factors to explain why dependence on western theories persists and shows no clear sign of abatement. The four factors are firstly, a history constructed by British administrators and scholars according to their Western mould, which is then accepted by local scholars and writers as a legitimate heritage; secondly, an attitude of awe towards and acceptance of Western literary paradigms as modern and superior while that of local literary tradition especially that informed by Islam as backward and inferior; thirdly, the role of crucial institutions such as Dewan Bahasa dan Pustaka (DBP) through whose authority as a government body perpetuates use of Western paradigms without much let or hindrance; and fourthly, the establishment of Western theories and ideologies as suitable conventions for Malay literature whose use guarantees neither dispute nor dissent. The sustained presence of the four factors underlines in no uncertain terms a glaring Western bias in Malay literary activities, whose stranglehold on Malay literature poses a real challenge indeed.

Keywords: Western-bias, historical constructs, literary conventions, institutional authority, pliant attitude, stranglehold.

\section{PENDAHULUAN}

Dalam konteks sastera Melayu, dekad 1990-an dan berikutnya menyaksikan kemunculan pelbagai 'teori' atau 'kerangka analisis' tempatan seperti Takmilah, Pengkaedahan Melayu, Pendekatan Firasat, Kata Kunci, Teksdealisme, Persuratan Baru dan sebagainya dengan pengertian 'teori' yang pelbagai, yang dalam banyak hal tidak pula memperlihatkan 
fahaman tentang 'teori' serta fungsinya yang tepat dan jitu. Namun, hakikat kemunculan pelbagai 'teori' tempatan ini memberi isyarat betapa tidak beresnya situasi sastera Melayu dewasa ini terutama situasi kritikan sastera yang lantas mengundang kemunculan teori-teori tempatan tersebut. Melatarbelakangi penampilan 'teori' tempatan ini ialah pengamatan bahawa penghasilan sastera dan lebih-lebih lagi kritikan sastera, ratarata dilaksanakan dengan menggunakan teori, kerangka dan idea-idea Barat, sesuatu yang dirasakan amat janggal dan tidak sesuai sama sekali. Ditegaskan bahawa hal ini kerana teori-teori Barat adalah produk konteks yang sangat berbeza daripada konteks tempatan sama ada dari segi agama, budaya, nilai atau pandang hidup, dengan itu tidak dapat berlaku adil kepada karya tempatan sama ada karya kreatif mahupun kritikan yang rata-rata merupakan hasil penulis dan pengkritik Melayu yang beragama Islam.

Ironisnya, walaupun ada pengamatan dan dakwaan tidak sesuainya teori dan idea Barat bagi hasil penulisan tempatan, serta sudah wujudnya pelbagai teori tempatan, sastera Melayu terus menerus memperlihatkan kebergantungan kepada teori Barat, dan kegiatan penulisan kreatif dan lebih-lebih lagi penulisan kritikan dengan jelas memperagakan teori-teori Barat secara terbuka dan nyata, malah dengan bangga, yakin dan penuh selesa. Mengapakah kontradiksi sedemikian berlaku? Mengapa di satu pihak diputuskan dengan berkobar-kobar dan penuh semangat bahawa teori Barat tidak sesuai dan perlu dicurigai, tetapi pada masa yang sama, malah dengan nafas yang sama, teori yang dicurigai itu didakap erat, diguna dan diperagakan sebagai wadah yang tepat, sementara penghasilan daripada penggunaannya diketengahkan sebagai penemuan yang tepat, berautoriti, wajar dihormati, dan dalam banyak hal, diberi pula pengiktirafan. Apakah yang memungkinkan teori-teori Barat dapat terus memainkan peranan yang begitu dominan dalam kegiatan penulisan sastera dan kritikan Melayu? Apakah yang menjadikan dunia sastera Melayu begitu kondusif sekali sebagai medan untuk bertakhtanya teori dan idea-idea Barat?

Tulisan ini ingin meneroka situasi sastera Melayu untuk melihat sebab-musabab yang memungkinkan kelangsungan teori Barat dalam kegiatan penulisan kreatif dan kritikannya. Untuk tujuan tersebut, tulisan ini akan mengetengahkan empat faktor utama yang turut sama memungkinkan 
kelangsungan, malah kebergantungan terhadap teori Barat. Empat faktor tersebut ialah Sejarah dan Bikinannya, Sikap dan Lenturannya, Institusi dan Autoritinya, dan akhir sekali Konvensi dan Kekebalannya. Kajian ini akan mengulas bagaimana empat faktor ini menjadikan sendeng-Barat sebagai posisi kegiatan sastera yang tidak memerlukan penjelasan atau pertikaian, jauh sekali apologi. Tegasnya, posisi sendeng-Barat sedia dihadirkan dalam dunia sastera Melayu sebagai posisi semestinya dan tidak terelak untuk kegiatan penulisan kreatif dan kritikan. Dalam membicarakan empat faktor ini, perlu ditekankan pembahagian kepada empat faktor bukan merupakan pembahagian yang tegar tetapi lebih merupakan pembahagian untuk urusan memudahkan fahaman tentang mauduk perbincangan, dan oleh itu beberapa pertindanan tidak dapat dielakkan. Sehubungan itu, sebelum membicarakan empat faktor tersebut, adalah wajar diberikan sedikit gambaran secara ringkas tentang tradisi dan warisan kita, serta implikasi pengabaian tradisi tersebut.

\section{Tradisi dan Warisan}

Kurun ke-16 dan ke-17 Masihi sering dirujuk sebagai kemuncak kecemerlangan kegiatan persuratan Melayu yang telah melahirkan tokohtokoh pujangga Melayu seperti Hamzah Fansuri, Nuruddin al-Raniri, Abdul Rauf Singkel, Syamsuddin al-Sumaterani atau Syamsuddin Pasai dan sebagainya. Periode tersebut jelas merujuk kepada tempoh masa selepas orang Melayu menerima Islam. Al-Attas (1972) menghujahkan kedatangan Islam merupakan satu tanda aras atau watershed yang cukup bererti dan signifikan kerana ia telah menganjakkan fahaman dan keyakinan masyarakat dewasa itu daripada yang tertumpu dan bergantung pada tahyul dan khurafat kepada pandang hidup yang berteraskan rasionalisme dan intelektualisme. Dengan kedinamikan pandang hidup tersebut, berserta tulisan jawi yang didasarkan kepada huruf Arab, dan kemajuan bahasa Melayu yang juga dipengaruhi dan diperkayakan oleh Islam, rantau ini dengan jelas dan tegas menjadikan Islam sebagai teras kegiatan persuratannya. Al-attas (1972: 63) menyimpulkan pengaruh Islam ke atas tamadun Melayu seperti berikut:

Sifat dan hakikat tamadun dan kebudayaan Melayu itu adalah sifat dan hakikat Islam, dan tiada dapat dipisahkan keduanya ini dalam konsepsi ilmiah yang tulen. 
Dalam magnum opusnya, The Heritage of Traditional Malay Literature: A Historical Survey of Genres, Writings and Literary Views (2004), Braginsky iaitu sarjana Rusia yang pernah bertugas sebagai Profesor di School of Oriental and African Studies (SOAS), London juga menegaskan betapa pentingnya peranan dan pengaruh Islam ke atas sastera Melayu, dan perlunya perkara ini diketengahkan. Hal ini disebabkan wujudnya kelompongan dalam kajian yang dijalankan oleh sesetengah sarjana Barat dan tempatan yang cenderung untuk menghujahkan sastera Melayu tidak lebih daripada pinjaman-pinjaman bersifat statik daripada India, Arab dan Parsi, dengan itu memberi pujian dan tumpuan berlebihan terhadap pengaruh-pengaruh tersebut dan sekali gus mengesampingkan peranan serta pengaruh Islam ke atas sastera Melayu. Sebagai contoh ialah pendirian R. O. Winstedt, sarjana Inggeris yang dianggap autoriti dalam sastera Melayu tradisional yang menegaskan bagaimana pengaruh India dan Jawa menyuntik tenaga luar biasa kepada kegiatan sastera, yang kemudiannya menurun apabila munculnya Islam di rantau ini. Bagi Braginsky, ribuan manuskrip yang terhasil dalam tulisan Jawi (antara 8,000 - 10,000 atau lebih) adalah bukti sahih betapa kedatangan Islam serta pengaruhnya merupakan satu fenomena luar biasa yang berjaya membuat transformasi budaya dan ideologi di rantau ini. Braginsky (1989: 42) menegaskan, "Bahagian yang paling berharga dalam warisan Melayu adalah kesusasteraan yang diciptanya setelah memeluk agama Islam.” Jelas, bagi kegiatan persuratan atau penulisan, implikasi kehadiran Islam dalam dunia ciptaannya cukup mendalam dan berpanjangan. Menurut Braginsky, kegiatan persuratan lantas memperlihatkan identiti dan ciri-ciri agama, sesuatu yang tidak menghairankan memandangkan kian mendalamnya proses Islamisasi waktu itu. Malah, Braginsky menegaskan sebenarnya keyakinan kepada Allah SWT Yang Satu, lebih daripada pertimbangan-pertimbangan teknikal yang memantapkan tradisi persuratan dan menjadikannya stabil, utuh dan mampu bertahan ratusan tahun lamanya. Tidak kurang pentingnya, karya-karya yang terhasil mula melihat dirinya dalam konteks yang lebih luas, iaitu sebagai sebahagian daripada tradisi yang jauh lebih besar, yang sama-sama dipasakkan secara teguh dan kukuh kepada prinsip-prinsip Islam seperti halnya dengan tradisi Arab dan Parsi. Hal ini terjadi kerana sudah terbentuk dalam kalangan masyarakat Melayu dewasa itu apa yang disebut oleh Braginsky (1989: 43) sebagai 'literary self consciousness' 
atau 'kesedaran diri sastera' yang menarik perhatian kepada soalan-soalan penting berkaitan proses penciptaan dan sastera itu sendiri seperti fungsi, peranan, matlamat, manfaat, struktur, nilai-nilai, ukuran dan sebagainya, yang kesemuanya menjurus kepada terbentuknya sebuah sistem yang mantap dengan prinsip-prinsip estetika dan puitika yang utuh, konsisten dan padu, yang sekali gus tercakup dalam batasan-batasan berkarya yang akur dengan Islam. Apa yang menarik, menurut Braginsky, ialah begitu jelasnya idea hierarki yang mendasari kegiatan penulisan, yang lantas mendorong Braginsky untuk memajukan sistem sastera Melayu tradisional yang terdiri daripada tiga sfera, iaitu 'sfera kesempurnaan rohani' (sphere of spiritual perfection) yang berstatus paling tinggi, 'sfera faedah' (sphere of benefit) dan akhir sekali 'sfera keindahan' (sphere of beauty). Disusun di tahap-tahap tertentu menurut kesesuaian, sfera keindahan yang mensasarkan hati atau nafs haiwani adalah yang paling rendah kerana “...cerita tentang cinta dan keajaiban walaupun memang menghibur hati sudah tidak lagi berguna (dan bahkan merugikan) bagi orang berakal iaitu kepada orang di peringkat akal" (Braginsky, 1989: 45). Begitulah susunan tertib yang membezakan dan seterusnya menempatkan karya dengan tepat dan 'patut' menurut kemanfaatan dan kemaslahatan manusia dalam usaha menuju kepada mengenali dan mengakrabi Khaliqnya. Dari sistem yang utuh ini, maka terbitlah rumus 'indah dan elok' dengan 'indah' merujuk kepada susunan yang harmonis dan teratur, sementara 'elok' pula merujuk kepada faedah, manfaat, kebijaksanaan, nasihat, peringatan, petunjuk, pedoman dan seumpamanya atau didaktisisme, yakni mengutamakan ilmu sebagai prinsip integral, yang kesemuanya terkawal menurut Islam. Tegasnya, dalam konteks persuratan Melayu, Islam hadir sebagai kriteria utama untuk urusan mengkategori, mengklasifikasi, dan lebih penting, urusan menilai. Hal ini sekali gus memperakukan keterlibatan Islam sebagai tenaga yang dinamik, kreatif dan konstruktif dalam persuratan Melayu.

Lakaran ringkas di atas bertujuan untuk menegaskan satu perkara penting sebagai latar kepada perbincangan penulisan ini. Perkara tersebut ialah hakikat kita memang sudah sedia mempunyai satu tradisi persuratan yang berteraskan Islam, yang utuh dengan sistemnya tersendiri, lengkap dengan bekalan 'kesedaran diri sastera', mempunyai prinsip-prinsip fundamental dan integral bagi urusan penulisan dan penilaian, di samping 
terkumpulnya khazanah yang cukup lumayan dan meyakinkan. Seterusnya, kedinamikan tradisi ini telah memastikan ia dapat bertahan ratusan tahun. Bagaimanapun, penjajahan Barat menandakan bermulanya proses peminggiran yang cukup berkesan sehingga tradisi yang utuh ini tidak lagi mendapat tempat dalam kegiatan penulisan karya kreatif dan kritikan sekarang. Noriah Taslilm (2010), pengkaji sastera tradisional, menyesali perkara tersebut yang dilihat sebagai satu kerugian yang amat besar.

Ternyata, proses peminggiran tradisi ini berterusan sehingga negara kita merdeka. Malah, diperhebatkan oleh kita sendiri apabila kita mengambil langkah-langkah yang jelas meruncingkan keadaan yang menjadikan cengkaman sendeng-Barat sukar untuk dileraikan. Situasi ini jelas kelihatan pada beberapa faktor yang akan dibincangkan di bawah ini.

\section{Sejarah dan Bikinannya}

Antara senjata ampuh yang digunakan oleh penjajah untuk memastikan kejayaan agendanya ialah menerusi pendidikan. Melalui pendidikan khususnya polisi-polisi yang dimaktubkan dan disalurkan melalui sekolah, maktab dan universiti, apa yang disebut oleh Al-Attas sebagai proses deislamisasi (deislamization) atau memutuskan orang Melayu daripada Islam, dilaksanakan dengan berkesan. Membicarakan proses deislamisasi ini, Al-Attas (1972), antara lain menarik perhatian kepada prioriti dan tumpuan yang diberikan oleh penjajah terhadap karya pra-Islam sehingga menutupi sumbangan Islam yang besar, menyebarkan wacana kolonial untuk menjustifikasikan kehadiran dan tindakan mereka selaku kuasa yang menyempurnakan misi kudus untuk mentamadunkan peribumi yang dikatakan kolot dan jauh ketinggalan zaman, memastikan ideologi sekularisme yang cukup berpengaruh di Eropah dewasa itu mencorak dan mewarnai pentadbiran kolonial termasuk aspek pendidikan, mengambil tindakan menggugurkan al-Quran sebagai mata pelajaran, memastikan penukaran tulisan jawi ke tulisan rumi yang lantas memutuskan orang Melayu daripada tradisinya yang tertulis dalam tulisan jawi, dan tindakantindakan lain yang bertujuan untuk menghakis kedudukan Islam dalam kehidupan orang Melayu. 
Terlepas daripada faktor pendidikan sekular dan implikasinya yang berbahaya tetapi kerap tidak disedari kerana tersembunyi, penulisan ini ingin mengalihkan pandangan kepada satu jalur spesifik daripada aspek pendidikan yang mempunyai kesan langsung ke atas sastera Melayu. Perkara tersebut ialah penabalan Abdullah bin Abdul Kadir Munsyi sebagai Bapa Kesusasteraan Melayu Moden dan implikasinya terhadap sastera kita hingga sekarang. Di kesempatan lain iaitu dalam tulisan "The Construction and Institutionalisation of Abdullah bin Abdul Kadir Munsyi as Father of Modern Malay Literature: The Role of Westerners" (Pembikinan dan Penginstitusian Abdullah bin Abdul Kadir Munsyi sebagai Bapa Kesusasteraan Melayu Moden: Peranan Barat) penulis (Ungku Maimunah, 2000; lihat juga Ungku Maimunah, 2003) telah menyusur galur mediasi atau keterlibatan sarjana dan pentadbir Barat dalam penabalan Abdullah yang melibatkan soal ideologi dan idea-idea sastera Barat, prasarana, peluang serta kelebihan yang mereka nikmati selaku penjajah yang mempunyai kuasa. Justeru, di sini hanya diketengahkan perkara-perkara yang relevan kepada mauduk perbincangan ini.

Penabalan Abdullah perlu difahami berlatarkan apa yang diperikan sebagai jenis penulisan yang lumrah dewasa itu dan perbandingannya dengan tulisan di Eropah, seperti yang tertera pada petikan dalam buku Segala Jenis Hikayat Ilmu Kepandaian yang telah Jadi di Negeri Eropah (dicetak pada 1843) yang terjemahannya ke bahasa Melayu diusahakan oleh Abdullah dengan kerjasama Alfred North, mubaligh Kristian bangsa Amerika yang menawarkan khidmatnya kepada London Missionary Society, yang juga merupakan murid Abdullah:

Sebermula maka ada-lah dalam negeri Eropah itu pada tiap-tiap tempat belajar-nya itu ada-lah suatu ilmu yang dipelajari oleh segala kanak-kanak itu maka ia-itu di-namai ilmu hikayat tetapi hikayat itu bukan-nya seperti hikayat-hikayat yang ada di-sebelah sini. Maka ada-lah yang kebanyakan-nya hikayat yang di-pakai orang se-belah sini penuh dengan cherita jin, pari, dewa, mambang, gergasi, naga dan geruda dan jenis-jenis rupa dan perkara yang belum pernah dilihat dalam dunia atau akhirat (dlm. Noriah Taslim, 2010: 163-164, ejaan asal dikekalkan). 
Demikianlah fahaman terhadap tulisan-tulisan dewasa itu yang menjadi pegangan North, Abdullah, dan sarjana-sarjana Barat lain seperti yang akan dilihat nanti.

Seperti yang diketahui umum, penabalan Abdullah rata-rata disandarkan kepada autobiografi beliau, iaitu Hikayat Abdullah (cetakan pertama 1849) dan Pelayaran Abdullah ke Kelantan (cetakan pertama 1837/1838) yang merakamkan secara jelas dan terperinci pengalaman beliau belayar ke Kelantan dan juga perihal kehidupan beliau termasuklah persekolahannya, keluarganya, adat resam masyarakat sekelilingnya, pengalaman pergaulannya dengan orang-orang Inggeris seperti Raffles, Milne, Crawfurd dan sebagainya. Seperti yang dinyatakan oleh Alfred North, dan diakui sendiri oleh Abdullah, penulisan kedua-dua autobiografi tersebut adalah atas 'saranan' dan 'tunjuk ajar' North menurut apa yang lazim dilakukan oleh orang Barat apabila mereka belayar, mengembara atau menulis riwayat hidup sendiri. Berdasarkan saranan North tersebut, maka terhasillah autobiografi berkenaan, iaitu tulisan yang berupa rakaman rinci hasil tanggapan Abdullah terhadap perkara-perkara harian yang diamati dan dialaminya. Tulisan beliau lantas diperikan sebagai 'berpijak di bumi nyata.' Tulisan tersebut dikatakan memperlihatkan kelainan yang sangat ketara dan signifikan berbanding tulisan-tulisan yang hadir dewasa itu yang rata-rata berlegar pada mitos, legenda, mambang dan peri, seperti yang dijelaskan oleh kutipan di atas.

Ternyata, autobiografi Abdullah memperlihatkan anjakan yang amat ketara dari segi tumpuan dan cakupan, iaitu dari cerita-cerita mambang dan peri kepada pengalaman kehidupan harian yang digambarkan secara rinci dan realistik. Perihal 'berpijak di bumi nyata' ini jugalah yang diketengahkan oleh sarjana-sarjana Barat (dan kemudiannya oleh sarjana tempatan) sebagai kewajaran tepat bagi penabalan Abdullah sebagai Bapa Kesusasteraan Melayu Moden. Justeru, tulisan-tulisan sarjana dan pentadbir Barat seperti North sendiri, Turnbull, Wilkinson, Skinner, Josselin de Jong, Teeuw dan Roolvink (lihat Ungku Maimunah, 2000) secara konsisten memperakukan realiti fizikal yang berlegar pada kehidupan harian yang dirakamkan oleh Abdullah secara rinci dan realistik itu. Di bawah ini diturunkan beberapa kutipan dari Kisah Pelayaran Abdullah ke Kelantan (1960) sebagai contoh 
betapa tegapnya pijakan tulisan Abdullah di bumi nyata, sehingga menarik perhatian sarjana dan pentadbir Barat untuk tanpa ragu-ragu menobatkan beliau sebagai Bapa Kesusasteraan Melayu Moden:

Dan lagi seperti memakai pakaian penuh dengan kotor dan daki, empat lima bulan yang tiada dibasuh kain bajunya, serta dengan busuk baunya, penuh tuma, sambil duduk menindas tuma... (22)

Syahdan, adalah rumah-rumah mereka itu atap lagi perbuatannya tidak senonoh. Maka di bawah rumahnya penuhlah dengan longkang dan sampah-sampah. Maka adalah beberapa rumah yang saya masuk ke dalamnya sebab hendak melihat peraturannya. Maka saya lihat darihal tempat tidur mereka itu dan perkakas mereka itu, dan daripada makan minum mereka itu, sekalian dengan kekotoran adanya; lagi tiap-tiap rumah itu busuk baunya... (65-66)

Bermula, sahaya lihat hal orang-orang dalam negeri itu miskin belaka. Lagi dengan kelakuan malas dan lali sepanjang hari. Dan kebanyakannya pula anak-anak raja dan hamba raja pada tiap-tiap kampung dan jalan, dan pakaian mereka itu tiada bagus, penuh dengan daki dan kotor badannya. Tetapi pada tiap-tiap orang ada empat lima batang campak buang dan sebilah keris dan serta cenangkas; itulah kerjanya memikul senjata ke hulu ke hilir... (28)

Maka terlalu banyak semak-semak pada keliling rumahnya, lagi tiada dengan peraturan rumah-rumahnya, sebuah di sini dan sebuah di sana ada yang dalam hutan ada yang di pantai; ada yang berpagar, ada yang tiada; masing-masing dengan sukanya. Demikianlah sepanjang sungai itu, setompok di sini, setompok di sana. Dan lagi terlalu kotor di bawah rumahnya. Maka tiap-tiap rumah itu adalah limpahan di bawahnya dan sampah bertimbun-timbun. Serta masuk, maka penuhlah bau busuk itu ke dalam hidung. Dan yang ada semaksemak, dan yang sehari-hari dibubuhnya asap dari bawah rumahnya mengasap nyamuk...dan segala pakaian mereka itu semuanya habis hitam dan tidak kelihatan mata kainnya itu, adanya... (10)

Atas kekuatan begitu realistiknya tulisan Abdullah inilah R. J. Wilkinson (1907: 60), pentadbir kolonial, pada tahun 1907 menabalkan Abdullah sebagai Bapa Kesusasteraan Melayu Moden. Penabalan ini disempurnakan dalam buku Papers on Malay Subjects (POMS), iaitu projek yang diarah, dibiayai dan disokong oleh pemerintah Inggeris; tegasnya, 
dengan kekuatan dan autoriti Inggeris. Seterusnya, penerbitannya dalam POMS menjadikan tulisan Wilkinson tersebut secara rasmi sebagai 'ilmu' tentang sastera Melayu khususnya ilmu tentang sastera, iaitu sejarahnya (tokoh pemisah/ pengikut/ tiada pengikut), periodisasinya (tradisional/ transisi? / moden), bentuknya (tiruan/ pinjaman/ saduran), dan sudah barang tentu, 'moden' atau tidak modennya sastera Melayu, yang sekali gus meletakkan tulisan sebelum Abdullah sebagai 'tradisional' dengan konotasi 'tidak moden.'

The pioneer of the new literature was the well-known writer Abdullah, who was born at Malacca and came, during his boyhood, under the influence of Sir Stamford Raffles... His literary ventures began with the composition of short poems on current events such as the great fires that devastated the Singapore of those days... His most famous work, however, is his own autobiography, the Hikayat Abdullah, which was written at the request of an English friend. Though open to serious criticism from the point of view of style, Abdullah's works ... deal with questions of everyday life... His name stands out as the one distinction of that early period...

Perintis sastera baharu ialah penulis terkenal Abdullah yang dilahirkan di Melaka dan banyak dipengaruhi oleh Sir Stamford Raffles pada zaman remajanya ....cubaan awalnya menulis karya sastera bermula dengan karangan syair-syair pendek tentang peristiwa semasa seperti kebakaran besar yang memusnahkan Singapura dewasa itu... Namun, tulisannya yang terkenal ialah autobiografinya Hikayat Abdullah yang ditulis atas permintaan seorang kawannya yang berbangsa Inggeris. Walaupun dikritik serius dari segi stail, karya Abdullah berlegar pada soal kehidupan seharian... Nama beliau terukir sebagai perbezaan nyata zaman tersebut ${ }^{2}$.

Seterusnya pada tahun 1940 Za'ba (1940: 142) menulis dalam Journal of the Royal Asiatic Society Malayan Branch atau JMBRAS, iaitu jurnal yang didukung oleh pemerintah Inggeris dan dianggap berautoriti, seperti berikut:

Modern Malay literature began with Abdullah bin Abdul Kadir Munsyi, the first writer to depart from the old tradition of supernatural romance and legendary history and to record contemporary events in a novel Autobiography and "Voyage to Kelantan"...His extolling 
of everything English, too, at the expense of the old Malay rajas and their regime has excited prejudice and even resentment and there have been articles in the vernacular press castigating him for his exaggerated Anglophile attitude and accusing him of disloyalty to his own people.

Sastera Melayu moden bermula dengan Abdullah bin Abdul Kadir Munsyi, iaitu penulis pertama yang menyimpang daripada tradisi lama yang berlegar pada cerita-certita sakti dan sejarah bersifat legenda. Sebaliknya beliau merakam peristiwa kontemporari dalam bentuk baru, iaitu Autobiografinya dan dalam "Pelayaran ke Kelantan" ... Sanjungan beliau terhadap semua yang berasal dari Inggeris, melalui bandingan negatif dengan raja-raja Melayu dahulu dan pemerintahan mereka, sering menimbulkan prasangka serta kejengkelan, dan terdapat tulisan dalam akhbar tempatan mengecam sikap keinggerisan beliau yang melampau dan juga tuduhan bahawa beliau tidak setia kepada bangsanya sendiri.

Sebagai sarjana tempatan yang dihormati, 'ilmu' sastera Melayu tersebut diperkukuhkan kerana kini ia diabsahkan oleh peribumi yang bukan calang-calang orangnya. Tinjauan tulisan-tulisan tentang 'kemodenan' sastera Melayu tidak memperlihatkan perubahan hingga kini. Buku sejarah sastera Melayu, Modern Malay Literary History, Jilid I dan II, keluaran Dewan Bahasa dan Pustaka pada tahun 1992 mengajukan 'fakta' yang sama, dengan hujah dan kewajaran yang tidak jauh berbeza. Begitu juga dengan kurikulum sekolah dan universiti yang juga memperlihatkan fakta yang sama hingga kini.

Peranan realisme yang begitu penting dan definitif dalam 'ilmu' sastera Melayu tidak dapat dipertikaikan. Jika penabalan Abdullah digunakan sebagai kayu ukur, maka fahaman realisme kelihatan seolah-olah tertumpu hanya pada soal dunia tumpuan tulisan beliau, iaitu dunia manusia berbanding dunia dewa-dewa. Hal ini tidak benar kerana sebagai sebuah pakej pemikiran intelektual dan seni, realisme mencakupi banyak aspek lain yang sangat penting seperti fahaman dan takrif kebenaran, realiti dan ilmu. Namun begitu, dalam konteks penabalan Abdullah, aspek yang menjadi tumpuan dan dianggap begitu ketara ialah anjakan dari dunia mitos ke dunia manusia biasa. Perkara ini tidak menafikan keistimewaan-keistimewaan Abdullah yang lain seperti individualitinya, keberaniannya mengkritik 
orang Melayu termasuklah raja dan golongan istana, dan penggunaan apa yang disebut sebagai ‘bazaar Malay' atau bahasa Melayu pasar, yang turut diajukan sebagai faktor untuk mengukuhkan penabalannya. Namun, seperti yang terserlah pada kutipan-kutipan di atas, hakikat tulisan beliau 'berpijak di bumi nyata' adalah satu anjakan yang cukup signifikan.

Penumpuan perbincangan terhadap anjakan tersebut tidak pula membatal, mencair atau tidak melayakkan realisme sebagai fahaman yang mendasari penabalan Abdullah. Hanya sanya dalam konteks penulisan Abdullah seperti disebut di atas, peralihan ke dunia nyata merupakan satu anjakan yang besar dan signifikan, yang pada pandangan sarjana dan pentadbir Barat mewajarkan beliau diberi gelaran Bapa Kesusasteraan Melayu Moden. Justeru, dalam memahami pakej realisme ini, perlu diingat apabila Wilkinson (1907) dan Za'aba (1940) menobatkan Abdullah sebagai Bapa Kesusasteraan Melayu Moden, tulisan kedua-dua tokoh ini lebih berlegar pada soal anjakan yang dibuat oleh Abdullah (selain sifat individualistik dan bahasa pasarnya), iaitu anjakan yang sangat ketara pada konteks zaman itu, yang tulisannya memang rata-rata senang dengan mitos dan legenda. Hal ini berbeza dengan keadaan dewasa ini, iaitu para novelis tidak lagi menulis dan para pengkritik tidak lagi menilai karya sastera yang tumpuannya masih berlegar pada dunia mambang dan peri, dewa dan dewi. Kini, realisme tidak lagi bererti tidak menulis pasal mambang dan peri kerana perkara tumpuan ini sudah beres diselesaikan, dan watak yang menghuni dunia fiksyen Melayu memang manusia dan bukannya dewadewa. Justeru, fahaman tentang pemanfaatan realisme dalam konteks sastera dewasa ini bukan lagi tertumpu pada anjakan kepada perkara-perkara harian (everyday occurrences) yang merupakan pertimbangan pokok dewasa itu, tetapi lebih kepada aspek realisme yang lain, seperti cara manifestasinya dan kewajaran yang diketengahkan, seperti yang akan dilihat nanti di bahagian subjudul lain.

Perbincangan aspek sejarah di atas menyerlahkan beberapa perkara penting tentang soal kesendengan-Barat ini. Pertama, sejak dari awal lagi sejarah sastera Melayu yang kemudian menjadi sejarah 'rasmi', adalah bikinan Barat yang bertitiktolakkan fahaman intelektual dan seni Barat yang bernama realisme. Perjalanannya yang dirintis, diperkukuh dan dilestarikan 
oleh orang Barat adalah satu proses untuk menyediakan dan menjinakkan orang Melayu kepada idea-idea Barat, sesuatu yang terbukti jelas berjaya dilakukan apabila hingga kini kita masih menggunakan sejarah bikinan Barat tersebut. Tegasnya, minda orang Melayu dibentuk supaya tidak akan merasa janggal dengan idea Barat, sementara para penulis Melayu pula telah disediakan untuk menerima idea-idea sastera Barat dengan selesa. Ternyata, penabalan Abdullah membenarkan peribahasa Melayu 'lulus jarum, lulus kelindan.' Bermula dengan 'lulusnya' realisme, sastera Melayu tidak merasa canggung untuk menerima idea-idea lain, hasil perkembangan teori-teori Barat terkini seperti pascamodenisme, pascakolonialisme, new historicism, feminisme, dan ism-ism seumpamanya.

Selain itu, penerimaan orang Melayu tentang sejarah sasteranya yang dibikinkan untuknya oleh orang Inggeris dengan sendirinya menggariskan kehebatan dan kemajuan orang Barat. Mungkin bagi orang Inggeris membikinkan sejarah adalah sesuatu yang wajar memandangkan pada tanggapan mereka orang Melayu tidak tahu erti 'sejarah' seperti yang difahami oleh Barat. Menurut Bottom, "History to the Malays has not until recently been either a science or an art, but an entertainment. Accuracy, completeness, organized expositions were not the vital principles" (dlm. Noriah, 2010: 226) (Sehingga baru-baru ini, sejarah bagi orang Melayu bukan satu sains atau seni tetapi adalah hiburan. Ketepatan, kelengkapan, penjelasan yang tersusun tidak merupakan prinsip yang penting). Justeru, 'sejarah' sastera Melayu yang lengkap dengan tokoh, periodisasi, bentuk dan kewajaran bagi setiap kategori dan klasifikasi menjadi bukti superioriti Inggeris berbanding Melayu. Apabila keistimewaan dan kehebatan Barat telah diterima, maka proses lulus jarum, luluslah kelindan menjadi kenyataan dalam dunia sastera Melayu seperti yang akan dilihat dalam perbincangan aspek-aspek selanjutnya.

\section{Sikap dan Lenturannya}

Perbincangan tentang 'sejarah dan bikinannya' di atas antara lain menyerlahkan penerimaan orang Melayu terhadap sejarah sastera mereka yang dibikin oleh Barat, dengan itu memperakukan sama ada secara langsung atau tidak langsung kehebatan keintelektualan Inggeris yang 
tidak dapat ditandingi oleh mereka. Sikap memandang tinggi terhadap orang Inggeris/Barat ini berlaku bukan sahaja semasa zaman penjajahan tetapi berterusan selepas itu, yakni selepas penjajah Inggeris dan Belanda sudah meninggalkan tanah jajahan rantau ini sama ada Tanah Melayu mahupun Indonesia. Malah, sikap menyanjung Inggeris/Barat ini diteruskan dengan bersemangat - dan dalam banyak hal dengan penuh kebanggaan oleh peribumi sendiri, dengan itu memperkukuh dan memperpanjangkan tanggapan tentang superioriti Inggeris.

Memperkatakan soal sanjungan Inggeris ini, contoh yang paling mudah tentulah Abdullah Munsyi sendiri yang secara terang-terangan memperakukan kehebatan Inggeris, kekaguman beliau sendiri terhadap Inggeris, dan kelemahan orang Melayu apabila dibandingkan dengan Inggeris, seperti yang selalu beliau lakukan dalam tulisannya. Beberapa contoh pengakuan Abdullah (1974: 73 - 74) sendiri memadai untuk membenarkan tanggapan ini:

Sebermula maka adalah sifat Tuan Rafffles itu, aku lihat tubuhnya sederhana. Tiada tinggi dan tiada rendah, tiada gemuk tiada kurus. Dahinya luas, alamat besar himmahnya. Dan kepalanya buntar, bincut ke hadapan, alamat berakal. Dan rambutnya warna perang, alamat berani. Dan telinganya lebar, alamat banyak penerangan...bibirnya nipis, alamat pandai berkata-kata. Dan lidahnya manis, dan mulutnya luas, dan lehernya jinjang, dan warna tubuhnya tiada putih bahana, dan dadanya bidang...

... [Sultan Husin] Tubuhnya tambun...kelihatan empat persegi... pendeknya...Tiada ketahuan rupa...kepalanya kecil...lehernya tenggelam...Mukanya lebar...matanya juling...mulutnya luas... perutnya gendut berlipat-lipat...suaranya garau...di mana ia duduk ia berdengkur... bila berkata-kata menengking-nengking...tiada kuasa membawa dirinya...

[Raffles]...Syahdan maka adalah tabiatnya itu kulihat sentiasa di dalam berfikir juga. Maka terlalu pandai ia memberi hormat akan orang, serta dengan manis mukanya berbahasa dengan orang. Encik dengan encik, tuan dengan tuan. Dan lagi banyak ia menaruh kasihan akan orang. Maka tangannya terbuka kepada orang miskin. Dan lagi terlalu pandai ia bercakap dengan tersenyum-senyum... dan lagi, jikalau barang suatu perkara yang didengarnya itu, tiadalah boleh 
sudah dengan sedikit, melainkan sampai kesudahannya. Dan lagi adalah selalu ia suka tinggal di dalam tempat sunyi. Maka tiada apa lain pekerjaannya melainkan menulis dan membaca kitab-kitab.

Maka inilah kelakuan yang kulihat terlalu jauh bezanya antara orang Melayu dengan orang putih. Adapun adat Melayu, kalau sudah menjadi isteri orang besar-besar itu, makinlah bertambah-tambah congkaknya dan malasnya... Bangun pun pukul sepuluh-sebelas, maka minum. Duduk sebentar, tidur juga sampai petang, duduk mengadap tempat sirih... Maka isteri Tuan Raffles itu kulihat tangan kakinya pantasnya seperti lipas kudung. Lepas satu, satu pekerjaannya. Lepas bekerja rumah, menjahit, lepas menjahit, menulis. Maka butalah mataku belum pernah melihat ia tidur tengah hari, atau baring-baring dengan senangnya, melainkan dalam pekerjaannya dan usahanya pada tiap-tiap hari... (82)

Berdasarkan kutipan-kutipan di atas, gelaran 'tali barut Inggeris' (stooge of the English) yang diberikan kepada Abdullah itu mungkin boleh difahamkan. Namun, terlepas daripada Abdullah Munsyi, mereka yang tidak ditanggapi sebagai 'tali Barut Inggeris' atau tidak menganggap diri mereka sedemikian juga memperlihatkan sikap yang sama. Sikap ini telah dibaca dengan tepat oleh Inggeris sehingga memungkinkan mereka merumuskan sikap tersebut sebagai sifat lumrah orang Melayu secara keseluruhannya dan bukannya sifat pengecualian atau kes-kes terpencil, seperti yang terserlah pada laporan yang memperkatakan tentang tulisan Jawi, iaitu tulisan milik Melayu:

The Roman character is associated in the Malay mind with vigour and intelligence of white races, while the Arabic character, associated with the study of the Koran, seem unsuited for the practical purpose of life. (dlm. Mohd. Sidek, 1989: 93 -94).

Pemikiran orang Melayu mengaitkan tulisan Roman dengan dinamisme dan kepintaran bangsa kulit putih, sementara tulisan Arab yang dikaitkan dengan membaca al-Quran, dilihat tidak sesuai dengan matlamat praktik kehidupan ini.

Dengan sikap demikian, adalah tidak menghairankan apabila negara yang sudah pun di ambang kemerdekaan dan orang Melayu pasti akan bebas daripada penjajahan Inggeris, mereka tetap berpegang pada pandangan hebatnya tulisan rumi berbanding tulisan jawi sekali gus bererti 
memperakukan superioriti Barat dan kelemahan mereka sendiri. Pada tahun 1954 di Kongres Bahasa Melayu Kedua, orang Melayu sendiri melalui Kesatuan Guru-guru Melayu Singapura (KGMS) mengambil inisiatif menggantikan tulisan jawi dengan tulisan rumi menerusi cadangan berikut:

Kongres Persuratan Melayu Malaya yang bersidang hari ini mengambil keputusan sudah sepatut-nya-lah Tulisan Rumi di-resmikan menjadi tulisan Persuratan Melayu dengan tidak menghapuskan Tulisan Jawi sahingga masa yang akan menentukannya. Cadangan ini di-sokong oleh Asas '50 (ejaan asal dikekalkan, dalam Abdullah Hassan, 2007: 24).

Walaupun untuk seketika selepas itu tulisan Jawi dapat bersaing dan bertahan dengan tulisan rumi, ternyata kedudukannya jelas terpinggir. Implikasi yang jelas dan sangat signifikan daripada keputusan tersebut ialah terputusnya orang Melayu daripada tradisi dan khazanahnya yang kaya yang tertulis dengan tulisan jawi. ${ }^{3} \mathrm{Hal}$ ini sudah barang tentu meninggalkan lompong yang dengan mudah dapat diisi oleh tradisi dan idea-idea Barat yang memang sudah sedia berpengaruh dewasa itu.

Keadaan di Indonesia lebih lantang terhadap pemujaan Barat. Pendirian Indonesia ini penting kerana kuatnya pengaruh sastera Indonesia ke atas sastera Melayu, sama ada sebagai sumber buku, tokoh-tokoh contoh dan model penulisan, sekurang-kurangnya pada dekad-dekad tersebut. Antara perkembangan sastera Indonesia yang terpenting dan berpanjangan pula kesannya ialah polemik kebudayaan tahun 1930-an yang dalam banyak hal menggariskan secara definitif pendirian sasterawan Indonesia terhadap Barat dan tradisi sastera Barat. Sutan Takdir Alisyahbana, tokoh dan aktivis sastera Indonesia tersohor yang pernah mengajar di Universiti Malaya (UM) sebagai profesor, tanpa berselindung mengesyorkan agar 'Otak Indonesia harus diasah menyamai otak Barat!' (1977a: 42). Perakuan Sutan Takdir Alisyahbana tentang kehebatan Barat dan perlunya kita berguru dengan Barat dapat dilihat di beberapa kutipan di bawah ini:

... Orang Timur harus berguru kepada orang Barat. Tetapi meski bagaimana sekalipun tidak enak bunyinya semboyan, bahwa kita harus belajar pada Barat, meski bagaimana sekalipun sedih hati kita 
memikirkan hal yang demikian dalam hal ini rasanya kita tidak dapat memilih (ejaan asal dikekalkan, 1977b: 19).

Tetapi hasil yang didapat dengan didikan Barat dalam dua tiga puluh tahun ini telah lebih dari cukup memberi harapan dan keyakinan kepada kita, bahwa dengan jalan itu kita akan maju ke muka (ejaan asal dikekalkan, 1977c: 65).

Sebabnya semangat keindonesiaan yang menghidupkan kembali masyarakat bangsa kita yang berabad-abad selaku mati itu, pada hakekatnya kita peroleh dari Barat... Malahan perkataan "Indonesia" yang kita banggakan sekarang ini ialah perkataan yang kita peroleh dari bangsa Barat. (ejaan asal dikekalkan, 1977a: 18).

Pendirian ini dikejapkan beberapa tahun kemudian dalam satu utusan rasmi, iaitu "Surat Kepercayaan Gelanggang” yang diterbitkan oleh Majalah Siasat pada 22 Oktober 1950 oleh mereka yang kemudian dikenali sebagai Angkatan 45. Slogan angkatan tersebut yang dilaungkan dengan penuh keyakinan ialah: "Kami adalah ahli waris yang sah dari kebudayaan dunia... ." Ternyata, yang dimaksudkan dengan 'dunia' ialah dunia Barat dan bukannya dunia Timur, jauh sekali dunia Islam.

Pendirian sastera Indonesia tersebut disambut baik oleh ASAS 50, yang turut memperakukan kehebatan Barat dan perlunya berguru dari Barat, seperti yang dilihat pada kutipan-kutipan di bawah ini:

Perlu kita menegaskan di sini bahawa datangnya pembaharuan dalam seni kesusasteraan Indonesia yang dipelopori Pujangga Baru mulai tahun 1930 yang lalu ialah disebabkan oleh adanya pengaruh dari aliran-aliran kesusasteraan Barat. Maka oleh itu tidak akan ada ertinya kalau kita akan mengatakan bahawa aliran kesusasteraan Barat tidak sesuai bagi kita apabila kesusasteraan Indonesia yang dianggap sesuai bagi kita itu sebenarnya adalah ditimbulkan oleh pengaruh dari aliran kesusasteraan Barat juga (Asraf, 1981a: 48).

Kita sangat menyedari kekurangan-kekurangan kita dalam dunia kesusasteraan Barat. Tetapi tidaklah dapat disangkal bahawa kesedaran untuk mencontohi Barat ini timbul dalam kalangan penulis-penulis muda kita setelah serapat-rapatnya mereka mengikuti perkembangan kesusasteraan Indonesia semenjak zaman angkatan 
Pujangga Baru pada tahun 1933 hingga zaman Angkatan 45 (Asraf, 1981b: 70).

...sekurang-kurangnya pada waktu ini, saya tidak hendak memanjangkan bahasan tentang hasil-hasil sastera Barat sungguhpun saya suka menganjurkan supaya setiap sasterawan muda kita harus banyak membaca hasil-hasil sastera Barat untuk mengambil contoh dalam menciptakan hasil-hasil sastera kita pula (Asraf, 1981c: 38).

Perlu diingat bahawa ASAS 50 merupakan badan sastera yang penting dan berwibawa dewasa itu, dan pendiriannya merupakan sumbangan yang cukup bererti terhadap pembentukan sikap yang tertentu terhadap Barat. Tambahan pula, ahli ASAS 50 hadir dalam khalayak sastera Melayu sebagai tokoh, dengan pengkhususan masing-masing seperti Keris Mas sebagai cerpenis, Usman Awang atau Tongkat Warrant sebagai penyajak dan Asraf sebagai pengkritik, yang sekali gus membekalkan mereka dengan autoriti terutama dalam bidang yang dikaitkan dengan mereka. Seterusnya, kedudukan mereka sebagai tenaga Dewan Bahasa dan Pustaka (DBP) memperkukuhkan kredibiliti mereka dan menjadikan suara mereka didengari, dihormati dan tidak diingkari.

Bahawa sikap sendeng-Barat ini telah dapat bertapak dengan kukuh dalam khalayak sastera Melayu itu terserlah dengan jelas apabila karya sastera yang terhasil tampil sebagai corong yang memihak kepada Barat. Pemujaan Barat kini mendapat satu suntikan baharu yang ampuh, iaitu karya sastera sendiri membawa mesej 'Barat itu superior' secara terus-menerus kepada pembaca dan peminatnya. Sementelahan, kehebatan Barat ini sering diungkapkan dalam bentuk perbandingan dengan orang Melayu yang digambarkan sebagai ketinggalan zaman. Sebagai contoh ialah novel Iakah Salmah? (1927) karya Ahmad Rashid Talu. Salmah, protagonis novel ini, distrukturkan oleh novel untuk tampil sebagai wanita moden yang cerdik pandai dan berjaya persis kerana mendapat manfaat dari pendidikan Barat. Selain daripada kepintaran akalnya yang ditonjolkan, pakaian gown Salmah yang jelas identiti Baratnya juga diketengahkan sebagai lambang kemajuan. Salmah juga digambarkan sebagai kebanggaan keluarganya yang turut menyokong sikapnya, sekali gus menjadikan sikap sendeng-Barat Salmah sesuatu yang tidak dianggap keterlaluan: 
Untung seribu kali untung bagi kita penduduk Straits dan Semenanjung telah dimasuki oleh bangsa Eropah. Bangsa yang sopan dan bangsa yang terpelajar. Kalau tidak, wallahu a'alam, apakah jadinya negeri kita ini pun saya tak tahu tapi pada fikir saya tentulah menjadi hutan rimba, semak belukar sahaja...Apatah penduduknya? Tentu barangkali tak ubahnya daripada bangsa-bangsa yang masih jauh daripada pengetahuan...iaitu seperti bangsa-bangsa Sakai, Semang serta Jakun (dlm. Noriah Taslim, 2010: 245 - 246).

Perihal hubungan dengan Barat sebagai faktor yang membawa kepada kemodenan tidak diselindung oleh novel ini. Malah, watak ini diketengahkan sebagai lambang kejayaan wanita Melayu yang dapat membebaskan dirinya dari kepompong mundur dan kolot Melayu persis kerana hubungannya dengan Barat. ${ }^{4}$

Merujuk kepada tempoh yang lebih dekat dengan kita, sikap sendengBarat dan ironi kesendengan tersebut dapat dilihat pada tulisan Reading Approaches in Malay Literature: Critical Theory in the Making (2010) oleh Zawiah Yahya, bekas profesor teori kritikan dan pengajian pascakolonial. Selaku sarjana yang berlatarbelakangkan sastera Inggeris dan mendalami kajian pasca kolonial, pendirian beliau terhadap bekas penjajah adalah jelas. Di satu kesempatan di Filipina, beliau (1999: 8) pernah menggesa supaya kita "...unseat England, Europe, and the United States of America as the centre of our universe and replace them with the centrality of our own country and our own region." (...kita perlu guling England, Eropah dan Amerika Syarikat sebagai pusat dunia kita dan menggantikannya dengan memusatkan negara kita dan rantau kita). Walaupun diungkapkan dalam konteks pengajaran sastera Inggeris, apa yang terserlah dengan jelasnya ialah utuhnya posisi Zawiah yang mengesyorkan strategi serampang dua mata apabila berdepan dengan bekas penjajah, iaitu menolak kebergantungan terhadap Barat di satu pihak dan mengetengahkan perspektif kita sendiri di pihak yang lain, “...the procedure should involve resisting eurocentricity on the one hand and making meaning from our own cultural base on the other."(13) (di satu pihak caranya ialah perlu menentang pemusatan Eropah, sementara di pihak yang lain ialah membikin makna daripada asas kebudayaan kita sendiri). Malah, Zawiah bertalu-talu mengingatkan peri pentingnya diperjuangkan perspektif kita sendiri untuk urusan interpretasi 
dan penilaian seperti yang dijelaskan beliau, iaitu: "we will approach a text with our own cultural schema to interpret ..." (14) (untuk urusan interpretasi, kita akan menangani sebuah teks dengan skema budaya kita sendiri...), dan lebih tegas lagi: "we have to think that the power to prescribe what must or must not be included for ourselves is in our own hands. "(12) (penekanan ditambah) (kita perlu berfikir bahawa kuasa untuk menentukan apa yang mesti dimasukkan atau ditolak untuk diri kita, terletak di tangan kita sendiri).

Berbalik kepada buku Reading Approaches in Malay Literature: Critical Theory in the Making, dalam buku tersebut Zawiah membicarakan kerangka analisis hasil cetusan sarjana dan penulis tempatan seperti Pengkaedahan Melayu, Takmilah, Puitika Sastera Melayu, Teksdealisme, dan Persuratan Baru atau PB oleh Mohd. Affandi Hassan. Judul buku Mohd. Affandi yang memuatkan idea PBnya ialah Pendidikan Estetika daripada Pendekatan Tauhid. Kemasukan perkataan 'tauhid' pada judul buku tersebut dengan serta-merta memancarkan identiti dan teras Islamnya. Dalam penilaiannya terhadap buku ini, Zawiyah menyesali apa yang dilihat sebagai ketegaran PB kerana memasakkan kriteria penilaiannya kepada Islam, yang lantas menjadikan skema penilaiannya begitu keras dan kaku. Zawiyah lalu membandingkannya dengan kerangka Barat yang membenarkan kebebasan untuk 'bermain' kerana tidak mengikat kreativiti penulis seperti halnya dengan PB yang bertitiktolakkan taklif dan mengamalkan prinsip berkarya menurut lunas-lunas yang dibenarkan oleh Islam. Kata Zawiah;

Such a paradigm of absolutism has little room for the kind of shifting subjectivity, autonomy, verbal acrobatics and flights of fancy which allows the post-modern Western writer to do what he likes with his material, and which allows contemporary critics since Derrida to celebrate relativity and difference in an endless chain of possibilities. Western tradition believes that such freedom will engender creativity." (23).

Sebuah paradigma yang begitu tegar tidak ada ruang untuk subjektiviti yang berubah-ubah, autonomi, mainan lisan dan khayalan yang menerawang yang membolehkan penulis Barat pascamoden untuk melakukan apa sahaja terhadap bahan mereka, dan membenarkan para pengkritik kontemporari sejak Derrida untuk merayakan kenisbian dan perbezaan dalam rangkaian kemungkinan- 
kemungkinan yang tidak ada penghujungnya. Tradisi Barat meyakini bahawa kebebasan sedemikian akan melahirkan kreativiti.

Di tempat lain dalam buku yang sama, Zawiah mengulangi apa yang dilihatnya sebagai ketegaran PB:

Such a demanding yardstick seems to disqualify almost the entire corpus of contemporary critical and creative writings in Malay literature that had been written from a more secular perspective. If this yardstick is forced on these works, the result will be a foregone conclusion. It is like fitting a round peg in a square hole. The critic will end up flogging a dead horse. It then becomes no longer intellectually challenging to sift through details and textual evidence if the conclusion is already writ in stone (60).

Satu tuntutan yang begitu tegar kelihatan tidak melayakkan hampir keseluruhan korpus tulisan kreatif dan kritikan kontemporari dalam sastera Melayu, yang rata-rata ditulis dari perspektif yang lebih sekular sifatnya. Seandainya kriteria ini dipaksakan ke atas karya-karya tersebut, kesudahannya dengan mudah dapat diduga. Ia sama seperti melakukan sesuatu yang jelas tidak sesuai. Akhirnya, pengkritik hanya membuang masa kerana tidak ada hasil yang bermakna. Seterusnya, secara intelektual ia tidak lagi bererti dan mencabar untuk menapis perincian-perincian dan bukti-bukti tekstual sekiranya keputusannya dari awal-awal lagi sudah dimeterai pada batu.

Dalam menilai PB, ternyata Zawiah tidak memperlihatkan keprihatinan atau penghayatan terhadap hakikat konteks PB dihasilkan, tradisi yang melatarbelakanginya dan sasaran utama gagasan tersebut, iaitu penulis Melayu beragama Islam (walaupun tidak terhad kepada mereka). Jelas dan diakui, PB bukan terhasil daripada hasrat Mohd. Affandi untuk turut sama melompat masuk ke dalam bandwagon (atau pihak) pascakolonialisme dan menulis kembali kepada kuasa kolonial Barat ala the empire writes back. Hal ini demikian kerana Mohd. Affandi tetap akan mempertikaikan ism-ism yang digunakan oleh penulis Melayu sekiranya bertentangan dengan Islam walaupun jika ism-ism tersebut tidak berasal dari Barat atau bekas penjajah. PB sesungguhnya ingin menempatkan semula Islam sebagai tonggak kegiatan mengarang para penulis Melayu, dengan itu mengembalikan tradisi persuratan Melayu yang berteraskan Islam. 
Namun, sebagai seorang pengkaji pasca kolonialisme, tidakkah Zawiah dapat melihat PB sebagai usaha sarjana tempatan untuk mengembalikan tradisi yang telah terputus lantaran kolonialisme. Oleh itu, usaha seperti ini perlu dihayati atas termanya sendiri? Tambahan pula, Zawiah sendiri pernah menggesa supaya kita menggunakan skema budaya kita sendiri untuk menginterpretasi teks. Jika demikian, mengapakah skema Barat dengan takrif dan fahaman 'kreativiti' dan tuntutan-tuntutan totok dan pukal dari 'Western tradition' dengan idiosinkrasi tokoh-tokohnya seperti Derrida dipaksakan ke atas PB walhal pada bahagian awal buku yang sama, Zawiah sendiri telah pun mengaku pascamodenisme dan Islam memang berantakan? Tidakkah Zawiah sendiri sebenarnya yang cuba memaksakan a square peg in a round hole? (melakukan sesuatu yang sudah jelas tidak sesuai). Ternyata, gesaan beliau supaya dipelihara perspektif sendiri dengan mantap sesungguhnya sudah hilang tanpa kesan; kebalikannya pula yang berlaku. Adakah ini menunjukkan bahawa Zawiah sendiri sebenarnya eurosentrik? Jelas, semangat dan laungan berkobar-kobar untuk 'unseat' (guling) Barat tidak lebih daripada retorik kosong semata, sementara hakikatnya ialah cengkaman sendeng-Barat ternyata sukar untuk ditanggalkan dari psyche Melayu, terutama sekiranya penggantinya berteraskan Islam.

Dalam konteks yang berlainan tetapi relevan dan berkaitan, buku Mohd. Affandi ini kecundang untuk memenangi Hadiah Sastera Malaysia 1992/ 1993 kerana ditewaskan oleh buku Teori dan Kritikan Sastera Melayu Tradisional (1993) oleh Noriah Taslim. Kejayaan buku Noriah, menurut para pengadil, disebabkan kecekapan dan kejayaannya menangani teori-teori Barat, sedangkan Pendidikan Estetika daripada Pendekatan Tauhid (cetakan pertama 1992, cetakan kedua 2005) mengajukan sastera menurut kaca mata Islam, walaupun gagasan tersebut adalah cetusan sarjana tempatan dan merupakan usaha asli untuk menghasilkan kerangka tempatan berbanding penerapan teori-teori Barat yang telah sedia ada. Panel pengadil menghujahkan seperti berikut:

...karya Mohd. Affandi Hassan telah didapati baik daripada segi idea utama dan pendekatannya yang berlandaskan ajaran tauhid daripada Islam. Walau bagaimanapun... 


\begin{abstract}
Buku Teori dan Kritikan Sastera Melayu Tradisional karya Noriah Taslim... pengarang menilai semula kajian-kajian dan model yang terdahulu seperti yang dibuat oleh Propp, Bausani, Ingram, Bremond, dan lain-lain, dan menyesuaikan serta menerapkannya kepada Sastera Melayu Tradisional... berjaya mempertalikan tentang permasalahan Sastera Melayu Tradisional, terutamanya genre dan kewujudannya, dengan teori-teori Barat dan kesesuaiannya... satu-satunya buku dalam tahun yang dinilai yang memperlihatkan kesungguhan menerapkan teori-teori Barat secara kritis dalam kesusasteraan Melayu Tradisional...

(Laporan Hadiah Sastera Malaysia 1992/ 1993, Dewan Sastera, Disember 1994: 88).
\end{abstract}

Di luar konteks sastera, sikap memuja Barat juga menjadi sebahagian daripada pendirian dan tindak-tanduk orang Melayu, iaitu sikap yang meliputi bukan sahaja masyarakat umum tetapi golongan bangsawan dan elit. Sebagai contoh ialah peristiwa lawatan Duli Yang Maha Mulia Sultan Abu Bakar yang tercatat dalam sejarah sebagai Bapa Johor Moden (Father of Modern Johor). Baginda merupakan Raja Melayu pertama diundang ke istana Ratu Victoria di England dan undangan tersebut Baginda anggap sebagai satu penghormatan yang luar biasa. Sejajar dengan itu, liputan Majalah Lidah Teruna (26 November 1920, Bil. 12) tentang peristiwa tersebut menunjukkan betapa orang Melayu menghargai undangan berkenaan kerana datangnya daripada Ratu Barat:

\begin{abstract}
...seorang Raja yang masyhur namanya dan bijaknya seperti "Abu bakar" siapa seorang Raja Melayu yang pertama kali mengibarkan mahkotanya di seluruh Eropah dan bergoncang tangan dan santap semeja dengan seorang Raja Perempuan yang termasyhur besar dan adilnya di seluruh dunia iaitu “Queen Victoria” Queen kita juga (dlm. Noriah, 2010: 230).
\end{abstract}

Namun, sikap sendeng-Barat ini dapat dikatakan terpancar dengan jelasnya pada pengenalan (1953: XII) terhadap karya Hikayat Abdullah yang ditangani bersama oleh Datoek Besar, tokoh tempatan (Indonesia) dan Roolvink, profesor Belanda dan pakar pengajian Melayu, apabila merumuskan tentang pemodenan sastera Melayu dengan cara ala berjenaka tetapi tidak terlepas dari sindiran tajam, iaitu sindiran yang turut disertai 
dan disokong oleh orang tempatan. Antara lain, dua orang tokoh ini membuat kenyataan berikut: "Abdullah itu seolah-olah bikinan orangorang Inggeris. Dapat rasanja dikatakan: Tak ada orang Inggeris tentu tak ada pula Abdullah!" (ejaan asal dikekalkan. Tanda seru dalam teks asal). Lanjutan logik daripada dakwaan ini atau subteksnya ialah: kalau tidak kerana Inggeris, sastera Melayu akan terus terperuk sebagai sastera yang ketinggalan zaman dan tidak dapat berbangga kerana sudah menjadi "moden". Justeru, orang Melayu perlu berterima kasih kepada Inggeris/Barat kerana memodenkan sastera mereka. Berdasarkan perbincangan tentang sikap orang Melayu terhadap orang Inggeris, bacaan subteks sedemikian tidaklah keterlaluan.

Perbincangan di atas dan kutipan-kutipan yang disertakan menunjukkan antara lain satu perkara penting, iaitu sanjungan Barat dilakukan oleh orang Melayu sendiri dengan penuh kerelaan dan kebanggaan. Lebih dari itu, hal ini juga bererti merelakan diri mereka untuk menerima apa yang mereka lihat sebagai kelemahan sendiri yang jauh ketinggalan berbanding Barat. Setelah meletakkan diri mereka sendiri di bawah Barat, adakah kesendengan terhadap Barat perlu dilihat sebagai lanjutan yang logik? Dengan kata lain, adakah ini bererti sikap dan amalan sendeng-Barat mereka perlu kita fahami dan tidak wajar dipersoalkan? Justeru, sekiranya sendeng-Barat ini hadir pada masa sekarang, kesendengan tersebut juga perlu difahami kerana ia bukan penjelmaan baharu tetapi adalah satu kesinambungan dari sikap, pendirian dan amalan yang sudah tertanam dengan kejapnya dari dahulu lagi? Malah, setelah berhempas-pulas menguasai tatacara menulis kembali (write back) kepada kuasa yang pernah menjajahnya dan berikrar untuk menumpas Barat sang penjajah, orang Melayu tetap berlari balik kepada Barat untuk mendapatkan pengabsahan dan perakuan Barat terhadap kebenaran kajian, penemuan dan pandangan yang diketengahkannya. Ternyata, sikap sendeng-Barat telah menguasai psyche sarjana dan penulis Melayu. Seterusnya, sendeng-Barat ini mendapat suntikan yang lebih bererti apabila ia direstui dalam bentuk yang lebih rasmi iaitu apabila ia diinstitusikan, seperti yang akan dilihat di bawah ini. 


\section{Institusi dan Autoritinya}

Perbincangan tentang subjudul ini akan berlegar pada beberapa aktiviti signifikan yang mempunyai kesan nyata ke atas sastera dan kegiatan penulisan, yang kepentingannya bukan sahaja terletak pada isi kegiatan tersebut tetapi pada hakikat ia diinstitusikan, dengan itu menjadikannya agen ampuh untuk urusan perakuan, pengiktirafan, pengabsahan dan sebagainya, yang seterusnya sangat penting bagi pencorakan sastera dan kritikan sastera serta perkembangan dan kelangsungannya. Dalam konteks urusan-urusan tersebutlah perkataan 'institusi' dan 'penginstitusian' digunakan di sini.

Satu projek besar dan sangat signifikan dalam pembentukan dan perkembangan sastera Melayu ialah projek Anugerah Sastera Negara, iaitu anugerah tertinggi dan paling berprestij di negara. Hal ini dengan sendirinya menjadikannya pengiktirafan yang cukup bererti. Namun, lebih dari itu, projek ini diletakkan di bawah Kementerian Pendidikan Tinggi dengan menterinya sebagai pengerusi projek, sementara DBP adalah sekretariatnya dengan Ketua Pengarah DBP selaku Timbalan Pengerusi. Jelas, projek ini melibatkan intervensi politik dan birokrasi iaitu secara khusus DBP, dengan itu menjadikan ketetapan panel anugerah, sama ada dari segi kriteria penilaian, kewajaran yang diajukan, tuntutan yang ditetapkan dan seumpamanya, sangat berautoriti, dan lebih dari itu, rasmi statusnya. Justeru, laporan panel anugerah adalah dokumen penting sebagai petunjuk sahih sama ada sastera Melayu memperlihatkan kesendengan Barat atau sebaliknya, dan apa pula pendirian para hakim terhadap soal Barat dan pengaruhnya ke atas sastera Melayu.

Sebelum diteliti laporan panel anugerah sastera, adalah wajar dilakarkan secara ringkas beberapa ciri penting realisme memandangkan betapa penting peranan yang dimainkannya dalam sastera Melayu. Di kesempatan lain penulis telah membincangkan realisme secara agak terperinci (Ungku Maimunah, 2009); memadailah di sini dilakarkan secara ringkas beberapa ciri penting fahaman tersebut. Realisme, fahaman seni dan intelektual yang tercetus pada pertengahan kurun ke-19 di Perancis (iaitu tempoh Abdullah Munsyi sedang rancak menghasilkan tulisannya) menjadikan bentuk novel sebagai gandingannya, yang lantas menghasilkan 
novel realis. Tumpuan garapan realisme ialah masyarakat bawahan dan terpinggir, dan secara khusus sisi getir, hodoh, bobrok dan bejat. Pam Morris (2003: 3) menyimpulkan perihal tumpuan tersebut dengan padat dan tepat seperti berikut:

Yet undeniably realism as a literary form has been associated with an insistence that art cannot turn away from the more sordid and harsh aspects of human existence. The stuff of realism is not selected for its dignity and nobility.

Namun tidak dapat dinafikan realisme sebagai satu bentuk sastera telah dikaitkan dengan penegasan bahawa seni tidak dapat berpaling daripada aspek kewujudan manusia yang bobrok dan getir. Bahan realisme dipilih bukan kerana digniti dan kemuliaannya.

Tumpuan kepada kebobrokan diperikan oleh realisme sebagai gambaran objektif realiti sosial kontemporari (the objective representation of contemporary social reality), yang di satu pihak menolak apa jua yang berbentuk kerohanian, simbolik dan fantastik, sementara di pihak lain membuka jalan kepada kemasukan perkara-perkara jelik, hina-dina dan tabu seperti seks. Seterusnya, fokus kepada kebobrokan mempengaruhi aspek lain dalam penghasilan sebuah cereka termasuklah pilihan watak (terpinggir dan golongan bawahan) dan bahasa yang digunakan (kasar, kesat dan cabul) demi menyerlahkan realiti sosial kontemporari berkenaan. Untuk menangani pengisahan masyarakat yang bobrok, realisme memilih kaedah atau tatacara sains yang menekankan objektiviti, hasil dari pengamatan yang teliti dan laporan yang rapi. Justeru, realisme menjadikan pemerian, terutama pemerian ala inventori dan perincian sebagai satu kemestian. Hal ini penting bagi realisme yang menuntut supaya realiti yang dipaparkan itu dilakukan setepat mungkin dan tidak diselindungi atau diperindahkan.

Lebih penting dari itu, objektiviti sains yang dimanfaatkan oleh realisme disandarkan kepada indera yang lima sebagai penentusah (verification) segala perkara. Justeru, apa jua yang tidak ditentusahkan oleh indera yang lima tidak diterima sebagai realiti mahupun sebagai kebenaran atau ilmu. Tegasnya, dunia luaran atau dunia fizikal diterima sebagai tumpuan yang wajar berbanding dunia bukan-fizikal atau transenden. Realisme menyenangi fahaman seperti ini yang lantas menjadikannya 
sebuah fahaman yang bersifat sekular. Sebagai gandingan dengan novel (cereka prosa), cereka realis juga merayakan teknik-teknik baharu, sesuai dengan nama bentuk 'novel' yang bermaksud 'baharu'. Dalam bahasa sastera, teknik-teknik baharu ini disebut sebagai 'eksperimen'.

Penelitian laporan menunjukkan karya Sasterawan Negara (SN) terutama yang menghasilkan novel dan cerpen jelas menggunakan realisme dalam penghasilan karya kreatif mereka. Dalam memanfaatkan realisme, para SN sering memilih untuk mengakuri tuntutan realisme berbanding dengan menentang atau mempertikaikan tuntutan-tuntutan tersebut. Ia sangat jelas terdapat pada aspek tumpuan pengisahan kebobrokan dan watakwatak pinggiran. Begitu juga, pengisahan rata-rata terbatas kepada dunia luaran yang berpusat kepada aspek fizikal, yang seterusnya digambarkan secara terperinci.

Jika di pihak para SN realisme jelas menjadi pegangan bagi urusan berkarya, di pihak para hakim pula manifestasi realisme dalam bentuk yang akur kepada tuntutan realisme Barat seperti yang terdapat dalam karya-karya para SN diterima sebagai bukti keistimewaan dan kemampuan penulisnya di samping ketinggian mutu karya berkenaan, sama ada dari segi seninya atau apa yang diperikan sebagai pemikirannya. Karya-karya tersebut lalu diperakukan, disokong dengan hujah-hujah tertentu, dan diberi sanjungan melalui pujian yang positif. Hal yang jelas adalah penghasilan dan penilaian sastera Melayu di tahap yang tertinggi di negara memperakukan kesendengan Barat yang amat ketara. Seterusnya, perakuan panel anugerah sastera hadir sebagai dokumen rasmi yang berautoriti. Tegasnya, sendeng-Barat telah diinstitusikan, kejap sebagai autoriti yang didokong oleh kuasa politik, birokrasi dan institusi. Di bawah ini diturunkan beberapa kutipan daripada Laporan Panel Anugerah Sastera yang menunjukkan pendirian positif panel hakim terhadap fahaman realisme dan pemanfaatannya dalam karya kreatif:

\section{Laporan 1985 (A. Samad Said)}

"culture of poverty" [budaya kemiskinan] ...Keadaan serba kekurangan ini digambarkan oleh A Samad Said dengan terperinci sekali, di samping kesangsaraan ( $\mathrm{sic}$ ) yang timbul daripada suasana perang, ...kesangsaraan (sic) ...yang menjijikkan, adalah selaras 
dengan aliran realisme dan naturalisme dalam sastera (hlm. 15).

Rata-rata A. Samad Said memberikan penyorotan khas kepada masyarakat bawahan yang terlantar, masyarakat kekotaan pinggiran yang sebetulnya - drebar, buruh, pelacur dan peneropongannya dibuat tanpa romantis atau drama. Di sinilah letaknya keistimewaan A. Samad Said...lebih-lebih lagi keupayaan deskriptif yang terperinci, sarat dan tidak apologis. (hlm. 20).

\section{Laporan 1996 (Arena Wati)}

Karya-karyanya tidak terpisah dari realisme biasa, khususnya realisme permukaan. Aspek-aspek realisme dalaman yang cuba menyelami pemikiran yang lebih dalam sifatnya agak kurang (hlm. 25).

Meskipun pemerian Arena Wati lebih banyak melingkari hanya aspek-aspek realisme luaran tetapi ada kalanya usaha itu cuba mencernakan realisme dalaman secara yang cukup peka sehingga membawakan kesan daripada kisah yang penuh merangsangkan dan menghairahkan (sic) (hlm. 22).

\section{Laporan 1996 (Abdullah Hussain)}

Dia membataskan dirinya sebaik mungkin melaporkan segala apa yang dirasa, dilihat, atau didengarnya dengan setia dan jujur. Penilaian dan pandangan terhadap segala laporannya itu diserahkan sepenuhnya kepada pembaca (hlm. 28).

\section{Laporan 2009 (Anwar Ridhwan)}

"Dunia Adalah Sebuah Apartmen" mengemukakan apartmen sebagai satu simbol kehidupan manusia. Apartmen adalah dunia yang sempit, panas, seragam bentuknya dan kuat pengaruh Baratnya. Kehidupan yang cuba digambarkan ialah kehidupan yang dipengaruhi oleh cara dan nilai Barat seperti seks bebas dan ketagihan arak. Kehidupan watak-wataknya berkisar pada keseronokan semata-mata (hlm. 10).

Kutipan-kutipan di atas dengan jelas menunjukkan keakuran kepada tuntutan realisme selaku fahaman estetik Barat, yang kemudian diperakukan oleh panel anugerah sastera negara dan seterusnya diberi pengiktirafan tertinggi. 
Penginstitusian sendeng-Barat dalam sastera Melayu juga dimantapkan melalui bentuk lain yang tidak kurang dibekalkan dengan autoriti dan wibawa seperti peraduan atau pemberian hadiah. Seperti yang dilihat di atas, buku Noriah Taslim dipilih untuk mengatasi Pendidikan Estetika daripada Pendekatan Tauhid yang tidak memanfaatkan atau mengetengahkan teori Barat, malah mempertikaikannya. Hal yang sama dapat disaksikan pada buku Norhayati Ab Rahman, Puitika Sastera Wanita Indonesia dan Malaysia: Satu Bacaan Ginokritik (2012) yang kesendengan Baratnya tertera dengan jelas pada judul buku berkenaan. Buku berkenaan asalnya ialah sebuah tesis kedoktoran, memenangi dua hadiah iaitu Anugerah Akademik Negara 2013 bagi kategori Penerbitan Buku, Kementerian Pendidikan Malaysia 2014 dan Hadiah Sastera Perdana Malaysia 2012, Kategori Buku Kajian, Kerajaan Malaysia 2013, dengan itu mengejapkan lagi wibawanya. Dengan menggunakan teori sastera feminis cetusan Elaine Showalter, buku berkenaan merungkai sejumlah karya picisan dan juga karya pornografi seperti Saman oleh penulis Indonesia Ayu Utama yang sifat pornografiknya diakui sendiri oleh Norhayati dan juga khalayak sastera Indonesia. Namun, bersenjatakan teori ginokritik ala Showalter, karya-karya tersebut telah diistimewakan dengan pujian tentang keberanian dan kejujuran watak-watak wanita meluahkan berahi dan keinginan-keinginan sulit mereka secara terbuka dan tanpa segan silu. Buku yang memperakukan perkara-perkara tabu dan terlarang (dengan pujian keberanian dan keikhlasan) kemudian diabsahkan melalui hadiah dan pengiktirafan yang sekali gus membekalkannya dengan autoriti akademik. Kini, buku berkenaan menjadi bacaan wajib di sesetengah universiti, memasuki kurikulum serta kursus-kursus dan menjadi rujukan para pelajar dan pengkaji. Mohd Affandi Hassan (14 Oktober 2012), yang membawa perspektif Islam apabila memperkatakan buku ini, menulis:

Amaran yang boleh saya kemukakan kepada anda semua hanya tentang dua jenis malapetaka. Pertama, malapetaka intelektual, apabila anda disogok dengan maklumat palsu dan pengetahuan palsu tentang hakikat insan dan hakikat amal perbuatan mereka. Anda diajar untuk menerima kejahatan dan gaya hidup songsang sebagai pernyataan sebenar diri anda. Anda mungkin bebas melakukan apa saja yang anda mahu; tetapi ketika itu anda bukan lagi seorang manusia yang ada maruah dan harga diri, yang ingin dihormati dan diterima sebagai seorang yang baik. Feminisme tidak dapat memberi 
semua itu kepada anda. Kedua, malapetaka etika dan moral, yang kesannya sangat buruk dalam kehidupan anda, kerana anda tidak lagi dapat membezakan adab sopan berbanding dengan sikap biadab dan tidak lagi mementingkan kesopanan yang seharusnya ada pada manusia normal. Untuk memahami kenyataan ini, anda perlu perhatikan bagaimana novel-novel pilihan itu ditafsirkan berasaskan feminisme. Semua novel disetarafkan, tidak dibezakan dari segi kualiti, tidak juga dari segi pemikiran. Bayangkan bagaimana Saman mendapat pujian dan sanjungan tinggi, padahal novel itu adalah novel picisan dan novel lucah; dan melalui pujian itu anda diheret untuk menerima kebiadaban di dalam novel itu sebagai cara hidup anda sebagai seorang perempuan.

Perkara yang sama juga berlaku pada buku Mawar Shafie, Novel Intertekstual Melayu (2010), yang juga asalnya ialah sebuah tesis kedoktoran. Sama seperti buku Norhayati, buku Mawar juga memenangi dua hadiah iaitu Hadiah Sastera Johor Darul Takzim 2010 (Kategori Buku Sastera/ Drama) dan Hadiah Anugerah Inovasi Universiti Kebangsaan Malaysia (Kategori Buku Ilmiah Terbaik) 2011. Buku berkenaan menggunakan idea Barat intertekstualiti untuk merungkai beberapa buah novel termasuklah novel SN Anwar Ridhwan Naratif Ogonshoto. Menurut intertekstualiti, semua penghasilan teks baharu adalah hasil pinjaman, penyesuaian atau pemindahan dari teks sumber kepada teks yang ingin dihasilkan. Menurut Mawar, menyatakan Anwar Ridhwan telah memanfaatkan qissah Nabi Nuh (a.s.) sebagai salah satu sumber dalam menghasilkan novelnya itu. Dalam mengkategorikan teks sumber, Mawar tidak memberi pertimbangan bahawa qissah Nabi Nuh (a.s.) adalah sumber Islami berstatus wahyu dan wajar disantuni dengan cara tersendiri (Zulkarnain, 2011). Sebaliknya, qissah Nabi Nuh (a.s.) dilonggokkan dengan teks-teks lain termasuklah cerita rakyat yang penuh khurafat dan The Prince tulisan Machiavelli, dengan itu menafikan status wahyu qissah benar al-Quran, menurunkan status wahyu tersebut, dan lebih dari itu, 'mensetarakan' atau 'levelling' (istilah dan konsep Prof. Al-Attas, lihat Mohd. Affandi, 2014) al-Quran dengan teksteks biasa hasil fantasi liar dan bikinan manusia. Namun, seperti juga buku Norhayati, buku Novel Intertekstual Melayu juga dikebalkan dengan autoriti akademik dan menjadi buku rujukan para pelajar dan penyelidik sastera (untuk perbincangan lanjut tentang perkara ini, lihat Ungku Maimunah, 2016: 34 - 38, Mohd. Affandi, 2014). 
Perbincangan di atas menyerlahkan betapa kesendengan terhadap Barat dalam karya kreatif dan juga kritikan telah diterima, diperakukan dan diberi sanjungan tertinggi melalui hadiah yang paling berprestij di negara, dengan itu menjadikannya contoh dan ikutan. Sejajar dengan itu, ia juga dibawa masuk ke universiti, dijadikan bahan rujukan, kajian dan modal kuliah, sekali gus memberinya wibawa dan kehormatan akademik, untuk nanti diperpanjangkan oleh para penyelidik dan ratusan para pelajar dalam satu proses yang berulang dan berterusan. Penginstitusian sendeng-Barat memberinya kekuatan luar biasa kerana dilihat sebagai rasmi dan terjamin kesahihannya. Perihal hadiah dan sanjungan yang secara konsisten dirangkul oleh tulisan yang sendeng-Barat, dan pada masa yang sama terpinggir atau kecundangnya tulisan yang tidak sendeng-Barat, memberi keyakinan betapa benar dan sahihnya pendirian sendeng-Barat tersebut. Sanggahan, apabila timbul, akan dineutralkan, sesuatu yang tidak sukar dilakukan memandangkan sokongan padu dan autoriti di belakangnya. Sesungguhnya, sendeng-Barat ini makin mencengkam apabila ia diperkukuhkan oleh satu lagi mekanisme yang cukup ampuh iaitu konvensi dan kekebalannya seperti yang akan dilihat di bawah ini.

\section{Konvensi dan Kekebalannya}

Dalam konteks sastera, konvensi secara mudah difahami sebagai cara, gaya, sifat, unsur atau amalan-amalan sastera yang diterima, difahami dan dimaklumi oleh khalayak sastera (penulis dan pembaca) sebagai sesuatu yang lumrah. Ia dimanfaatkan dengan selesa kerana sifatnya yang sudah dikenali dan diterima. Penggunaannya yang kerap dan berterusan menjadikan kehadirannya dalam sastera (kreatif dan kritikan) stabil, dengan itu penggunaannya tidak dipersoalkan, jauh sekali dipertikaikan. Dengan kata mudah ia menjadi 'arus perdana', dan oleh sebab ia arus perdana, maka ia menjadi kebal.

Seperti yang diperlihatkan pada perbincangan subjudul-subjudul di atas, sendeng-Barat dalam sastera Melayu sebenarnya sudah menjadi ' $a$ given', sudah menjadi sebahagian daripada sastera Melayu, iaitu bahagian integralnya pula, yang kehadirannya seperti yang diperlakukan kepada sesuatu konvensi, tidak lagi dipersoalkan, jauh sekali dipertikaikan. Dalam 
sastera Melayu moden, mengakuri, berbanding menentang konvensi sendeng-Barat adalah lumrah.

Dalam sastera Melayu moden, satu manifestasi sendeng-Barat yang amat menonjol ialah pemanfaatan realisme sebagai dasar penulisan kreatif dan dasar penerimaannya dalam tulisan kritikan. Umpamanya, A. Samad Said (1992: 55) mengaku, "[S] aya memilih realisme kerana aliran ini saya kira boleh berkomunikasi sebaiknya dengan masyarakat saya." Laporan Panel Anugerah Sastera Negara 2009 yang menobatkan Anwar Ridhwan sebagai Sasterawan Negara memperuntukkan satu subjudul khusus berjudul "Jaringan Realisme dalam Cerpen Awal." Ruzy Suliza Hashim (2016: 127) pula memulakan tulisannya yang berjudul "Etnografi Melayu dalam Rontok dan Royan oleh Arena Wati" dengan kenyataan yang tegas, yang memerikan kepatuhan Arena Wati kepada realisme: "Rontok dan Royan nukilan Arena Wati merupakan novel yang mematuhi ciri-ciri realisme dalam pengkaryaan sastera." Laporan Panel Anugerah Sastera Negara 1985 (Laporan, 1986: 15) memuji karya A. Samad Said kerana patuh pada realisme dan naturalisme, "Keadaan serba kekurangan ini digambarkan oleh A. Samad Said dengan terperinci sekali... adalah selaras dengan realisme dan naturalisme dalam sastera." Ternyata, realisme disenangi dalam kalangan penulis kreatif dan juga pengkritik termasuklah panel hakim Anugerah Sastera Negara.

Seperti yang dijelaskan di atas, Rene Wellek memerikan realisme sebagai; "the objective representation of contemporary social reality" (dlm. Hemmings, 1974: 12) (gambaran objektif realiti sosial kontemporari), iaitu memaparkan masyarakat seperti keadaannya yang sebenar. Bererti, paparan tersebut adalah tepat dan persis seperti adanya dan tidak dihias atau diperindahkan. Demikian juga yang ditekankan oleh Grant (1974: 27), "realism commits itself to an exact, complete, and sincere reproduction of the social milieu, of the contemporary world..." (realisme mengabdikan dirinya untuk merakamkan persekitaran sosial dunia kontemporari dengan tepat, menyeluruh dan jujur). Dalam konteks sastera Melayu, penegasan realisme ini lumrah difahamkan sebagai 'kesusasteraan adalah cerminan masyarakat.' Dengan pemahaman yang demikian, adalah menarik untuk melihat kewajaran yang diketengahkan oleh para pengkritik yang menangani 
penggunaan realisme terutama apabila kebobrokan dan kebejatan moral digambarkan secara eksplisit seperti yang disyorkan oleh realisme. Di bawah ini diturunkan kewajaran yang diketengahkan oleh para pengkritik.

Dalam penelitiannya tentang cerpen 'Nafsu' oleh Shahnon Ahmad, Rahimah Abdul Hamid (2012) menarik perhatian kepada unsur-unsur erotik yang begitu ketara dalam cerpen berkenaan khususnya yang melibatkan watak utama Sharifah Berlian yang "Nafsu[nya] ... sebagaimana yang diperlihatkan oleh Shahnon begitu membara terhadap lelaki" lantas dia "mengimpikan tubuh Dolah, tukang kebunnya sendiri" (352). Rahimah seterusnya memberi beberapa kutipan daripada cerpen tersebut berupa gambaran-gambaran eksplisit 'nafsu' Sharifah Berlian. Tentang tumpuan Shahnon terhadap persoalan kebejatan moral serta gambaran Shahnon yang eksplisit dan jelas erotik itu, Rahimah menulis: "Bagi Shahnon, paparan tentang nafsu Syarifah Berlian yang membuak-buak itu adalah satu realiti dalam kehidupan manusia, lantas tidak perlu disamar-samarkan." (352) Dalam tulisan yang sama, yang menyorot cerpen-cerpen Shahnon, babak-babak kebejatan moral yang erotik, eksplisit dan mengghairahkan diwajarkan atas alasan ia "adalah peristiwa benar yang terjadi dalam kehidupan manusia" (352); atau ia "merupakan peristiwa yang lumrah terjadi dalam kehidupan masyarakat di kampungnya" (362). Rahimah menerima dan membenarkan gambaran-gambaran sedemikian dengan kewajaran dan belaan "[B]agi Shahnon, apa yang disuratkan dalam cerpen-cerpen di atas itu adalah peristiwa benar yang terjadi dalam kehidupan manusia." Seterusnya, Rahimah menghujahkan (353), “...hal itu perlu diperkatakan sejujurnya tanpa perlu disolekkan dengan perkataan yang muluk-muluk.” Ternyata, bagi Rahimah kejujuran dalam kepengarangan ialah mendedahkan kebobrokan sepersis mungkin. Kebalikannya ialah penipuan kerana tidak akur pada realisme, dan lebih penting lagi, telah menyimpang dari realiti.

Dalam kertas kerjanya "Paparan citra wanita dalam karya Shahnon: Realiti atau khayalan pengarang? yang dibentangkan di Seminar Pemikiran Sasterawan Negara Shahnon Ahmad," Siti Hajar Che Man (2012) yang meneliti watak-watak wanita Shahnon daripada perspektif feminisme, merumuskan Shahnon sebenarnya telah membisukan dan menafikan hak dan suara wanita sebagai mekanisme untuk menundukkan dan mengekalkan 
mereka di bawah kuasa lelaki. Antara lain, wanita dalam karya Shahnon sering hadir sebagai pelampias nafsu serakah lelaki. Namun, paparan eksploitasi wanita yang direalisasikan dalam babak-babak seks yang eksplisit dan erotik, menurut Siti Hajar, "[B]ukan salah Shahnon” (483). Hal ini kerana ia adalah hasil “... pemerhatian dan kepekaan Shahnon yang terperinci, mendalam, kritis dan tajam tentang perihal masyarakat ...Shahnon hanyalah penyampai maklumat semata-mata" (483). Justeru, walaupun paparan Shahnon mungkin “...begitu melampau hingga sampai ke tahap terlalu bersifat erotik, simbol sex, porno, atau pembaca menjadi lebih berang dengan gaya Shahnon yang sengaja excessive descriptions dan exaggerate dan kerap kali pula terlalu daring..." (472, italik dalam teks asal), ia dilakukan atas kewajaran perkara tersebut adalah realiti yang sebenar, yang perlu dirakamkan sejujurnya, seperti jua yang dihujahkan oleh Rahimah. Justeru, Siti Hajar menjawab sendiri soalan yang diajukan pada judul kertas kerjanya iaitu apa yang terlakar secara eksplisit dan erotik ialah realiti, dan penjelasan tersebut memadai sebagai kewajaran dan boleh diguna pakai dan dipertanggungjawabkan untuk menerima dan memperakukan bentuk paparan yang bersifat eksplisit dan erotik. Malah, Siti Hajar "menyarankan agar jadikanlah karya-karya Shahnon sebagai rujukan untuk terus menggilap karya-karya yang berkualiti" (488).

Kertas kerja yang dibentangkan oleh Mohamad Saleeh Rahamad pada Seminar Pemikiran SN Abdullah Hussain diberi judul "Kuala Lumpur Kita Punya: Paparan realiti sosial bebas nilai dan bebas ruang." Mohamad Saleeh memanfaatkan idea-idea tentang sastera yang dicetuskan oleh Hippolyte Taine, Lucien Goldmann dan Rene Wellek serta Austin Warren, yang antara lain menegaskan sastera adalah produk persekitaran sang penulis, dan analisis persekitaran akan membuahkan fahaman tentang karya berkenaan.

Apabila Saleeh Rahamad meneliti novel Kuala Lumpur Kita Punya (KLKP) (1967), beliau mengaku novel berkenaan yang mengisahkan pergaulan bebas anak-anak muda yang tinggal di Kuala Lumpur, bersifat pornografi dan memaparkan babak-babak seks secara eksplisit dan menggiurkan. Perihal sifat erotik dan pornografi itu, menurut Mohamad Saleeh, disebabkan dekad 1960-an menyaksikan bercambahnya karyakarya erotik yang menjanjikan jualan yang laris bagi penjual dan pulangan 
yang lumayan bagi penulis. Di samping itu, dekad tersebut juga belum tersentuh dengan gerakan dakwah Islamiah yang muncul pada dekad berikutnya. Dengan kata mudah, persekitaran yang melahirkan KLKP ialah yang mendorong terhasilnya karya-karya lucah. Justeru, Mohamad Saleeh menghujahkan paparan eksplisit babak-babak erotik dan memberahikan dalam KLKP adalah gambaran tepat realiti dewasa itu. Menurut beliau, "pengarang [adalah] perakam zaman dan ... perumus realiti sosial pada zaman itu" (14), dan Abdullah Hussain secara jujur dan tepat merakamkan realiti sosial dewasa itu untuk "memberikan kefahaman tentang budaya masyarakat pada waktu itu yang bebas nilai dan bebas ruang." Sekali lagi kewajaran 'itulah realiti' digunakan sebagai modal untuk menerima dan memperakukan karya pornografi.

Kewajaran yang sama juga diketengahkan oleh Muhammad Saiful Haq bin Hussin (2013) dalam kertas kerja beliau, "Perspektif seorang nasionalis dan realis-sosialis dalam Hati Muda Bulan Muda," yang dibentangkan di Seminar Pemikiran SN A. Samad Said. Meneliti watak Hamidah dalam cerpen 'Rita Hamidah' "yang tidak mendengar nasihat dan teguran...mengamalkan budaya kuning... dan bertukar-tukar pasangan..." (232), Muhammad Saiful Haq menganalisis tumpuan cerpen yang berlegar pada persoalan kebejatan dan watak-watak pinggiran seperti berikut: "Itulah realiti dalam masyarakat yang cuba dipaparkan oleh A. Samad Said melalui kekuatan karyanya" (235), yang lantas diperakukan oleh Muhammad Saiful Haq sebagai ‘kekuatan’ A. Samad Said.

Ternyata, perihal realiti masyarakat yang memang bobrok, yang perlu pula dirakamkan sepersis mungkin, dianggap memadai sebagai kewajaran untuk membenar dan memperakukan tumpuan kepada kebobrokan dan juga cara eksplisit kebobrokan dan kebejatan tersebut digambarkan. Inilah juga pegangan SN Shahnon Ahmad (1997: 36 - 45) apabila novelet beliau TIVI, yang mengisahkan hubungan sumbang mahram sebuah keluarga Melayu yang digambarkan secara eksplisit, dipertikaikan. Shahnon membidas khalayak sastera yang tidak memahami posisi beliau selaku penulis yang perlu mendedahkan realiti seperti adanya: 
Bukankah realiti masyarakat kita sekarang ini adalah realiti masyarakat lucah menuju kehancuran di luar duga? (39)

Bukankah realiti masyarakat kita sekarang ini sedemikian rupa? Banyak yang sudah melampaui batasan dalam persoalan melayani nafsu yang sememangnya tidak pernah puas terlayan pun sampai bilabila... Dan mereka bergelumang dalam babak-babak yang umumnya diterima sebagai lucah, erotika, dan pornografi. (43)

Jangan marahkan saya kalau terasa kelucuannya [kelucahannya?], terasa erotiknya, terasa pornografinya kerana saya hanya mematuhi tuntutan realiti masyarakat dalam berkarya. Saya tidak boleh berbohong dan cuba mengajak pembaca lari dari realiti masyarakat. Kelucahan, erotika dan pornografi itu adalah real; malah sudah pun melampaui batasnya di luar duga (penekanan dalam teks asal). (43)

Seterusnya bagi Shahnon, apa yang digambarkan oleh TIVI, dengan caranya itu, mendorong beliau untuk memerikan noveletnya itu sebagai 'karya mithali.' Pendirian Shahnon tersebut dipertahankan oleh Rahimah Abdul Hamid (2004: 27) yang melihat persoalan yang digarap oleh TIVI (sumbang mahram) serta cara ia digambarkan (eksplisit) menjadikan novelet tersebut "berjiwa Islam. Malah, karya nipis ini sebenarnya mendukung nilai-nilai mistik dan sufistik Islam yang halus dan mendalam."

Perbincangan di atas memperlihatkan betapa hampir seragam atau samanya kewajaran yang diajukan untuk menjelaskan kehadiran persoalan bobrok dan cara eksplisit persoalan tersebut ditangani dalam karya sastera. Dengan kata lain, setiap kali soal kebobrokan dan cara ia digambarkan bangkit, kewajaran yang sama - 'itulah realiti' yang akan diajukan oleh pengkritik dan penulis kreatif untuk menangani soalan tersebut. Sukar untuk diterima bahawa kewajaran yang sama itu adalah satu kebetulan. Penjelasan yang lebih munasabah ialah kewajaran itu merupakan sumber yang dapat dimanfaatkan dengan mudah, selesa dan yakin oleh sesiapa jua, sama ada penulis kreatif mahupun pengkritik. Kewajaran itu boleh dimanfaatkan kerana ia lumrah digunakan, sering didengari, mudah difahami, diterima dengan baik dan tidak disangkal setiap kali diajukan, malah dianggap ilmiah. Sekiranya keadaan memerlukan supaya ia dipertahankan, ia dapat dilakukan dengan menyandarkannya kepada autoriti Barat yang mencetuskan idea 
tersebut. Dengan kata lain, ia telah menjadi konvensi dan sebagai konvensi penggunaannya tidak dipersoalkan, jauh sekali dipertikaikan. Tegasnya, ia kebal. Dan kerana ia kebal ia memberi keyakinan yang bukan sedikit pada penggunanya (lihat Ungku Maimunah, 2011).

Mungkin dalam konteks keyakinan inilah kenyataan Azizi Haji Abdullah dapat difahami. Dalam bukunya, Kuras-kuras Kreatif, Azizi (2007) menjelaskan fahaman beliau tentang kegiatan menulis:

Pada masa itu [1960-an] karya kreatif berunsur lucah sering tersiar... Saya cuma nampak dunia kejahatan sahaja yang perlu ditulis jika mahu menjadi seorang penulis... (8)

...Bagi saya ketika itu, dunia penulisan ialah dunia yang penuh dengan kekotoran yang perlu dibongkar dan diceritakan kepada umum. Bagi saya ilham hanyalah boleh diangkat dari tempat kotor termasuk di dalam tandas... (9)

Seterusnya, Azizi menambah:

...Ini bukan salah saya. Yang salah ialah karya dan penulisan penulis lain yang mendedahkan dan menelanjangkan semua ini sehingga memberi keyakinan bahawa jika hendak menjadi penulis, dunia seperti inilah yang perlu dikecimpung $(9$, penekanan ditambah)

Sesungguhnya keyakinan Azizi itu terbit dari konvensi sastera: memperkatakan dan menelanjangkan dunia kekotoran sudah hadir sebagai amalan sastera dewasa itu, yang dipraktikkan oleh penulis-penulis lain. Justeru, tidak menghairankan apabila Azizi merasa begitu yakin untuk sama-sama memanfaatkan konvensi tersebut. Sehubungan perkara ini, ternyata sastera Melayu moden tidak memperlihatkan banyak perbezaan dari tahun-tahun 1960-an (lihat, umpamanya novel SN Arena Wati Panrita (1993) dan Cakra Waruga (2006); cerpen SN Anwar Ridhwan 'Dunia adalah Sebuah Apartmen' dan novel beliau Naratif Ogonshoto; dan tulisan para pengkritik seperti yang dibincangkan di atas), dan kelihatan akan berterusan. Tambahan pula, ada konvensi sastera yang dengan kekebalannya akan membentengi jenis tulisan sedemikian. Sesungguhnya, inilah realiti sastera Melayu moden. 
Soal realiti yang digambarkan oleh penulis kreatif dan dipertahankan oleh para pengkritik menarik perhatian kepada implikasi yang cukup serius. Seperti yang ditekankan oleh idea realisme Barat dan dipraktikkan dalam sastera Melayu seperti dilihat di atas, realiti yang dimaksudkan rata-rata berlegar pada dunia fizikal atau realiti yang dapat ditentusahkan (verify) oleh indera yang lima. Bererti, takrif 'realiti' tersebut dibataskan dan terbatas kepada realiti 'mata kasar'. Realiti sedemikian mengundang soalan bagaimanakah dengan realiti yang melampaui dunia fizikal tersebut, iaitu dimensi transenden, metafizik, atau yang berkait dengan soal kerohanian dan ketuhanan yang kewujudannya bagi penulis Melayu-Islam wajib diimani? Dalam posting beliau berjudul "Realisme sebagai puaka intelektual dan puaka akademik dalam perkembangan sastera Melayu moden" (14 Disember 2011), Mohd. Affandi Hassan merujuk bukan sahaja kepada sempitnya realisme Barat yang menyasarkan realiti fizikal semata tetapi memerikannya sebagai realiti semu (bermaksud pura-pura atau bukan yang sebenarnya) yang dibezakan dengan realiti hakiki. Mohd. Affandi merujuk kepada "hakikat realiti yang mempunyai dua wajah: realiti semu, yang menjadi pegangan Panel Anugerah Sastera Negara, para sasterawan, sarjana dan pengkritik sastera; dan realiti hakiki yang ditunjukkan oleh alQuran.” Seterusnya Mohd. Affandi menjelaskan, "kewujudan realiti hakiki itu mencorakkan perilaku manusia beriman (lihat bagaimana ahli fikir Firaun tunduk menyerah kepada hakikat realiti dan beriman) yang terpancar dalam kehidupan seharian mereka yang mereka pamerkan dalam cara berfikir, cara bertindak dan menilai sesuatu, dan cara mereka menentukan nilai-nilai moral mereka yang terpancar dalam konsep taklif yang menurut Shah Wali Allah mempunyai tiga rahsia itu." Berdepan dengan penjelasan seperti ini, dapat difahamkan mengapa Mohd. Affandi melihat realisme dalam sastera Melayu moden sebagai satu 'puaka'. Pada akhirnya, kata Mohd. Affandi (2002: 45), "sastera Melayu moden akan menjadi apendiks kepada sastera Barat sepenuhnya."

Perbincangan empat perkara di atas telah menyerlahkan betapa sendeng-Barat mencengkam sastera Melayu moden. Kepelbagaian cara dan bentuk cengkaman tersebut beroperasi dan direalisasikan - dari mekanisma institusi ke konvensi sastera menjadikannya satu cabaran yang amat serius kepada perkembangan sastera Melayu. Tambahan pula, selesanya sastera 
Melayu dengan cengkaman ini menjadikannya sesuatu yang bahayanya tidak disedari (insidious) yang cukup merosakkan. Cengkaman ini tidak boleh dipandang ringan atau dikesampingkan dengan alasan sastera Melayu masih terus berjalan, tulisan kreatif dan kritikan baharu terus dilahirkan dan tulisan-tulisan tersebut terus menggondol hadiah-hadiah berprestij. Namun, inilah sebenarnya padah sebuah cengkaman: ia tidak dilihat sebagai cengkaman yang menjerat dan membelenggukan. Memastikan ia disedari dan diakui sebagai ancaman dan seterusnya mengatasinya - adalah cabaran besar yang dihadapi oleh sastera Melayu.

\section{KESIMPULAN}

Perbincangan di atas telah menghujahkan empat faktor kritikal yang memainkan peranan penting dalam sastera Melayu, iaitu faktor Sejarah dan Bikinannya, Sikap dan Lenturannya, Institusi dan Autoritinya, dan Konvensi dan Kekebalannya. Faktor-faktor tersebut telah memupuk iklim sastera yang cukup kondusif terhadap kebergantungan kepada Barat sehingga sendengBarat bukan sahaja menjadi ciri jelas dalam penulisan kreatif dan kritikan Melayu, tetapi lebih penting lagi, merupakan satu cengkaman serius dan perlu ditangani dengan bijaksana agar penulisan kreatif dan kritikan Melayu tidak terus hanyut sebagai tiruan inferior sastera Barat.

Sesungguhnya cabaran cengkaman sendeng-Barat sudah pun bersambut. Sudah ada usaha untuk mempersoalkan sendeng-Barat tersebut dengan segala implikasi negatifnya. Sejajar dengan itu ialah usaha untuk mengembalikan tradisi persuratan Melayu yang bertunjangkan Islam. Gagasan Persuratan Baru atau PB cetusan Mohd. Affandi Hassan dipasakkan dengan kejapnya kepada keyakinan tauhid, dengan menjadikan taklif sebagai titik tolak kegiatan penulisan. PB hadir sebagai sebuah kerangka analisis bagi tulisan kreatif dan kritikan yang merayakan ilmu yang benar di sisi Allah SWT, dengan itu secara tuntas mempertikai dan seterusnya mencabar teori dan idea sastera Barat. Bukankah satu hipokrasi apabila di satu pihak kita bertempik gegak gempita perlunya teori tempatan yang dapat berlaku adil kepada karya kita, tetapi setelah disediakan alternatif, ia ditolak tanpa hujah yang mantap atau kritikan yang membina. 
Usaha PB ini wajar disokong, bukan diremehkan dan disaluti dengan andaian, prasangka dan konotasi negatif seperti: terlalu ideal (mengapa berpuas hati dengan yang mediocre?); kalau dilaksanakan akan hancurlah tradisi dan lenyaplah identiti kita (bukankah kesendengan Barat sudah pun menghakis tradisi dan identiti kita, sebaliknya PB berusaha untuk mengembalikannya?); ia sukar (bukankah emas perlu melalui proses pembakaran untuk mendapatkan emas tulen?); ia terlalu tegar kerana penilaiannya writ in stone (ketidakpastian, subjektiviti, terumbang-ambing adalah situasi ideal yang boleh menjamin mutu?); ia tidak praktikal (dari segi apanya yang tidak praktikal?); ia sangat anti-Barat (tidak benar. Salahkah sekiranya ia menyarankan agar teori Barat dimanfaatkan bukan secara totok tetapi dengan menjadikan Islam sebagai rujukan asas dalam menentukan kesesuaiannya?); pengamalnya boleh dikira dengan jari (kuantiti penentu kualiti?); ia tidak relevan untuk masa sekarang (apabila pornografi diterima sebagai seni tinggi, pelacur sebagai watak mithali, realiti tidak menggapai dimensi rohani: keadaan terdesak ini memang memerlukan PB). Meminjam (dan menyesuaikan) Shakespeare (kerana kata-kata tokoh Inggeris/Barat sahaja yang didengari!), "the Malay literary public doth protest too much, methinks." (pada pendapatku khalayak sastera Melayu terlalu banyak protes). Benar, banyak sungguh protes penulis, pengkritik, sarjana dan sasterawan Melayu. Adakah protes-protes tersebut benar-benar berasas? Atau, kita sebenarnya sedang menyaksikan sindrom "tak pandai menari, lalu dikatakan tanah yang lekuk-lekak."

\section{NOTA}

1 Makalah ini adalah penyesuaian daripada Ucaptama yang dibentangkan oleh penulis di Persidangan Buku Antarabangsa, 14 - 15 Disember 2016, Putra World Trade Centre (PWTC), Kuala Lumpur.

2 Semua terjemahan dari Bahasa Inggeris ke Bahasa Melayu adalah terjemahan bebas penulis.

3 Sama ada implikasi tersebut tidak disedari atau dimaklumi tetapi tidak dianggap signifikan dan relevan, bukanlah persoalannya di sini. Namun, padah keputusan tersebut dapat dilihat hari ini pada status tulisan jawi sekarang.

4 Dengan menggunakan kerangka feminis, Siti Hajar Che Man (2007: 75) dalam tulisan beliau berjudul "Pandangan terhadap wanita sejati dalam novel Iakah Salmah? karya Ahmad Rashid Talu” membaca watak Salmah seperti berikut: "Ahmad Rashid Talu mengawal Salmah sepenuhnya. Pemikiran Salmah telah didiskriminasikan. Cara bacaan ini juga menentukan Salmah mengalami penderaan mental kerana pengarangnya terlalu 
ambitious. Secara lebih halus, Salmah telah didera secara subtle untuk berlagak seperti wanita yang berpengalaman, walhal umurnya baru 15 tahun ...Bacaan kritik feminis menentukan Salmah telah dieksploitasi dan mengalami penderaan bawah sedar..." Bukan tujuan tulisan ini untuk menangani bacaan Siti Hajar, yang mengundang lebih banyak soalan daripada memberi jawapan. Apa yang jelas ialah bacaan beliau yang menggunakan kerangka feminis Barat tidak menghakis hujah tentang sikap pemujaan terhadap Barat, iaitu teras hujah tulisan ini.

\section{RUJUKAN}

A Samad Said. (1992). Antara bulan dan wira (Edisi Khas Sasterawan Negara). Kuala Lumpur: Dewan Bahasa dan Pustaka.

Abdullah bin Abdul Kadir. (1960). Kisah Pelayaran Abdullah ke Kelantan. Kuala Lumpur: Oxford University Press.

Abdullah bin Abdul Kadir. (1974). Hikayat Abdullah. Kuala Lumpur: Penerbitan Pustaka Antara.

Abdullah Hassan (Ed.) (2007). Kongres Bahasa dan Persuratan Melayu I - VI (1952 - 2002). Kuala Lumpur: Persatuan Penterjemah Malaysia.

Al-Attas, Syed Muhammed Naquib. (1972). Islam dalam sejarah dan kebudayaan Melayu. Kuala Lumpur: Penerbit Universiti Kebangsaan Malaysia.

Asraf. (1981a). Ke arah kesusasteraan Melayu yang membangun. Dlm. A. M. Thani (Pnyt.), Esei Sastera ASAS 50,47 - 52. Kuala Lumpur: Dewan Bahasa dan Pustaka.

Asraf. (1981b). Cita-cita kesusasteraan Melayu baru. Dlm. A. M. Thani (Pnyt.), Esei Sastera ASAS 50, 69 - 73. Kuala Lumpur: Dewan Bahasa dan Pustaka.

Asraf. (1981c). Nilai Sastera. Dlm. A. M Thani (Pnyt.), Esei Sastera ASAS 50, 27 - 39. Kuala Lumpur: Dewan Bahasa dan Pustaka.

Azizi Haji Abdullah. (2007). Kuras-kuras kreatif. Kuala Lumpur: Dewan Bahasa dan Pustaka.

Braginsky, V I. (1989). Sistem Sastera Melayu Klasik dan Penilaiannya. Dewan Sastera, Oktober, 42 - 51.

Braginsky, V I. (2004). The heritage of traditional Malay litertaure: A historical survey of genres, writings and literary views. Leiden: KITLV Press.

Datoek Besar \& Roolvink. (1953). Pendahuluan. Hikayat Abdullah. Djakarta: Penerbitan Djambatan.

Grant, D. (1974). Realism. London: Methuen.

Hemmings, F. W. J. (Ed.) (1974). The age of realism. Middlesex: Penguin.

Laporan Hadiah Sastera Malaysia 1992/1993 (Bahagian Pertama). (1994). Dewan Sastera, November, $12-18$.

Laporan Hadiah Sastera Malaysia 1992/1993 (Bahagian Akhir). (1994). Dewan Sastera, Disember, $77-89$. 
Laporan Panel Anugerah Sastera Negara 1985. (1986). Kuala Lumpur: Dewan Bahasa dan Pustaka.

Laporan Panel Anugerah Sastera Negara 1987. (1988). Kuala Lumpur: Dewan Bahasa dan Pustaka.

Laporan Panel Anugerah Sastera Negara 1996. (1996). Kuala Lumpur: Dewan Bahasa dan Pustaka.

Laporan Panel Anugerah Sastera Negara 2009. (2009). Kuala Lumpur: Dewan Bahasa dan Pustaka.

Mawar Shafie. (2010). Novel intertekstual Melayu. Bangi: Penerbit Universit Kebangsaan Malaysia.

Mohamad Saleeh Rahamad. (2011). Kuala Lumpur kita punya: Paparan realiti sosial bebas nilai dan bebas ruang. Kertas kerja. Seminar Pemikiran Sasterawan Negara Abdullah Hussain, Oktober, 19-20.

Mohd. Affandi Hassan. (2002). Era picisan dalam sastera Melayu: Shahnon, Azizi, Rohman Shaary. Dewan Sastera, Julai, $44-47$.

Mohd. Affandi Hassan. (2005). Pendidikan estetika daripada pendekatan tauhid. Kuala Lumpur: Dewan Bahasa dan Pustaka.

Mohd. Affandi Hassan. (2011). Realisme sebagai puaka intelektual dan puaka akademik dalam perkembangan sastera Melayu moden. (14 Disember 2011). Diakses melalui http://pbaru.blogspot.my/2011/12/realisme-sebagai-puakaintelektual-dan.html.

Mohd. Affandi Hassan. (2012). Teori sastera barat dalam tangan sarjana Islam. (14 Oktober 2012). Diakses melalui http://pbaru.blogspot.my/2012/10/ teori-sastera-barat-dalam-tangan.html.

Mohd. Affandi Hassan. (2014). Sesat dalam belantara maklumat: Peranan teori sastera Barat dalam sastera Melayu moden (Bahagian iii). (28 November 2014). Diakses melalui https://pbaru.blogspot.my/2014/11/sesat-dalambelantara-maklumat-peranan_28.html.

Mohd. Sidek bin Haji Fadzil. (1989). Pemikiran Barat moden - Sikap para cendekiawan Muslim dengan tumpuan di Alam Melayu. Tesis Doktor Falsafah yang diajukan ke Institut Bahasa, Kesusasteraan dan Kebudayaan Melayu (IBKKM), Universiti Kebangsaan Malaysia.

Morris, P. (2003). Realism. London: Routledge.

Muhammad Saiful Haq bin Hussin. (2013). Perspektif seorang nasionalis dan realissosialis dalam Hati Muda Bulan Muda. Dlm. Pemikiran Sasterawan Negara A. Samad Said. 215 - 248. Kuala Lumpur: Dewan Bahasa dan Pustaka.

Norhayati Ab Rahman. (2012). Puitika sastera wanita Indonesia dan Malaysia: Satu bacaan ginokritik. Pulau Pinang: Penerbit Universiti Sains Malaysia.

Noriah Taslim. (1993). Teori dan kritikan sastera Melayu tradisional. Kuala Lumpur: Dewan Bahasa dan Pustaka.

Noriah Taslim. (2010). Lisan dan tulisan: Teks dan budaya. Kuala Lumpur: Dewan Bahasa dan Pustaka. 
Rahimah Abdul Hamid. (2004). Karya kreatif berjiwa Islam. Dewan Sastera, September: $23-27$.

Rahimah Abdul Hamid. (2012). Debu Merah: Menyorot kreativiti Shahnon Ahmad tentang debu-debu dalam kehidupan masyarakat. Dlm. Pemikiran Sasterawan Negara Shahnon Ahmad. 348 - 366. Kuala Lumpur: Dewan Bahasa dan Pustaka.

Ruzy Suliza Hashim. (2016). Etnografi Melayu dalam Rontok dan Royan oleh Arena Wati. Dlm. Ungku Maimunah Mohd. Tahir (Pnyt.). Islam dan Pengaruh Barat dalam Kritikan. 127 - 141. Bangi: Penerbit Universiti Kebangsaan Malaysia.

Shahnon Ahmad. (1997). Azab Allah: Juzuk yang digeruni dalam sastera Islam. Dewan Sastera, Oktober, 36 - 45.

Siti Hajar Che Man. (2007). Pandangan terhadap wanita sejati dalam novel Iakah Salmah? karya Ahmad Rashid Talu. Dlm. Siti Hajar Che Man. Esei-esei Kritikan Feminis dalam Kesusasteraan Melayu. 68 - 79. Pulau Pinang: Penerbit Universiti Sains Malaysia.

Siti Hajar Che Man. (2012). Paparan citra wanita dalam karya Shahnon Ahmad: Realiti atau hanya khayalan pengarang? Dlm. Pemikiran Sasterawan Negara Shahnon Ahmad. 470 - 490. Kuala Lumpur: Dewan Bahasa dan Pustaka.

Sutan Takdir Alisyahbana. (1977a). Semboyan yang tegas. Dlm. Achdiat K. Mihardja (Pnyt.), Polemik Kebudayaan. 37 - 42. Jakarta: Pustaka Jaya.

Sutan Takdir Alisyahbana. (1977b). Menuju masyarakat dan kebudayaan baru. Dlm. Achdiat K. Mihardja (Pnyt.), Polemik Kebudayaan. 13 - 21. Jakarta: Pustaka Jaya.

Sutan Takdir Alisyahbana. (1977c). Didikan barat dan didikan pesantren: Menuju ke masyarakat yang dinamik. Dlm. Achdiat K. Mihardja (Pnyt.). Polemik Kebudayaan. 60 - 66. Jakarta: Pustaka Jaya.

Ungku Maimunah Mohd. Tahir. (2000). The construction and institutionalisation of Abdullah bin Abdul Kadir Munsyi as father of modern Malay literature: The role of westerners. Dlm. Smyth D. (Ed.). The Canon in Southeast Asian Literatures. 99 - 113. Surrey: Curzon Press.

Ungku Maimunah Mohd. Tahir. (2003). Between content and aesthetics, modernity in the writings of Abdullah Munsyi: The acclaimed father of modern Malay literature. Dlm. Ungku Maimunah Mohd. Tahir. Readings in Modern Malay Literature. 54 - 70. Kuala Lumpur: Dewan Bahasa dan Pustaka.

Ungku Maimunah Mohd. Tahir. (2009). Dinamika pemikiran sastera Melayu. Kuala Lumpur: Dewan Bahasa dan Pustaka.

Ungku Maimunah Mohd. Tahir. (2011). Pemartabatan 'realiti' dan 'realisme' ke status konvensi sastera dalam kesusasteraan Melayu. Kertas kerja Seminar Antarabangsa Kesusasteraan Melayu XI (SAKMXI), Universiti Kebangsaan Malaysia, 7 - 8 Disember. 
Ungku Maimunah Mohd. Tahir (Pnyt.). (2016). Islam dan pengaruh Barat dalam kritikan. Bangi: Penerbit Universiti Kebangsaan Malaysia.

Wilkinson, R. J. (1907). Malay Literature, Part 1. Romance, History, Poetry. Papers on Malay Subjects. Kuala Lumpur: The Federated Malay States Government Press.

Za'ba. (1940). Modern developments. Malayan Branch of the Royal Asiatic Society, Vol. XVII, Pt. III, Januari.

Zawiah Yahya. (1999). Your language, my culture: Domesticating English literature for the postcolonial classroom in Southeast Asia. Dlm. Luisa J. MallariHall (Ed.), Texts \& Contexts: Interactions Between Literature and Culture in Southeast Asia. 7 - 16. The Department of English and Comparative Literature. The Republic of the Philippines.

Zawiah Yahya. (2010). Reading approaches in Malay literature: Critical theory in the making. Bangi: Penerbit Universiti Kebangsaan Malaysia.

Zulkarnain Mohamed. (2011). Pendekatan $T a^{c}$ àmul-taklif dalam kajian sastera. SARI: International Journal of the Malay World and Civilization. 29 (1), $137-152$. 
